\title{
THE FIRST AMENDMENT IN A TIME OF MEDIA PROLIFERATION: DOES FREEDOM OF SPEECH ENTAIL A PRIVATE RIGHT TO CENSOR?
}

\author{
Patrick M. Garry ${ }^{*}$
}

\section{The Marketplace Metaphor in an Age of Abundance}

\section{A. A Media Society of 500 Channels}

Modern information technology offers not only more speech, but more ways to deliver that speech. Through the media, every kind of speech is readily available, sometimes with no more than the push of a finger. Many Internet users spend as much time avoiding speech as retrieving it. It is not unfeasible, therefore, that in an age of over-abundant information, freedom of speech may not have the same connotations as it did fifty years ago.

In the media society that America has become, new ways are being explored to combat the constant surge of unwanted information and to help the receiver control what he or she receives. ${ }^{1}$ Do-not-call lists are set up for people who wish to avoid being contacted by telemarketers. ${ }^{2}$ Laws are considered that would require Internet providers to furnish filtering software, and make cable and broadcast television channels carry outside ratings services to be used in connection with the V-chip. Under most First Amendment analyses, such measures would be seen as unconstitutional

* J.D., Ph.D., University of Minnesota. Currently, visiting professor of law, University of South Dakota Law School.

1. With the explosive growth of the Internet, "it is clear that society is demanding some method for shielding itself, or at the very least for shielding children ...." Thomas Nachbar, Paradox and Structure: Relying on Government Regulation to Preserve the Internet's Unregulated Character, 85 MinN. L. REv. 215, 218 (2000). Many of the public complaints or worries regarding the Internet involve sexually explicit material. Time magazine devoted a special issue to "cyberporn." See PhilipElmer-Dewitt, Cyberporn, Time, July 3, 1995, at 38. President Clinton told "horror stories about the inappropriate material for children that can be found on the Internet," and described how "children can be victimized over the Internet." President's Remarks Announcing Steps to Make the Internet Family Friendly, 33 WKLY. Comp. Pres. Doc. 1077 (July 16, 1997). Other critics worry about new communication technologies and their invasiveness of personal privacy. See, e.g., Paul M. Schwartz, Privacy and Democracy in Cyberspace, 52 VAND. L. Rev. 1609 (1999).

2. As of December of 2002, twenty-seven states had do-not-call lists or had pending legislation to create one. 
burdens on speech. According to the marketplace metaphor first articulated by Justice Holmes, the First Amendment has an interest in abundance: the more speech, the better. ${ }^{3}$ This interest has been steadily strengthened throughout nearly a half century of jurisprudence, during a time when it was assumed that only an expansive free speech law would allow for a vibrant exchange of information. But the marketplace metaphor, as well as the high premium it puts on sheer abundance, tends to ignore how American society has changed over the past half-century.

In a world of 500 digital television channels, twenty-four hour cable, and an Internet on which information-carriage increased ten-fold from 1997 to $2000,{ }^{4}$ the problem is not too little, but too much speech, and, especially in terms of the kind of speech needed for an informed self-government, too much of the "low value" speech. ${ }^{5}$ There has been an explosion in entertainment and in speech that is vulgar and sexually and violently graphic. ${ }^{6}$ In the American

3. Abrams v. United States, 250 U.S. 616, 630 (1919) (Holmes, J., dissenting) (articulating the marketplace metaphor), discussed in Patrick Garry, Oliver Wendell Holmes and the Democratic Foundations of the First Amendment, in Great Justices of the United States Supreme Court 125 (William D. Pederson \& Nomvdn W. Provizer eds., 1993). See also Owen K. Fiss, The Censorship of Television, in Eternally Vigilant: Free Speech in the Modern Era 257 (Lee C. Bollinger \& Geoffrey Stone eds., 2002). "From the First Amendment Perspective . . more speech is better." Id. at 268.

4. Madeleine Schachter, Law of Internet Speech 6 (2001).

5. See Eugene Volokh, The First Amendment: Problems, Cases and Policy Arguments 114-17 (2001) (discussing "low value" speech). For a discussion on the abundance of speech and information over the Internet, see Monroe E. Price, The Newness of New Technology, 22 CARDOZo L. REV. 1885, 1910-12 (2001) (citing the "abundance of the Internet" and the consequences of "[i]nformation overproduction"). For an overall discussion on information overload in contemporary society and its effects, see generally Kristan J. Wheaton, The Warning Solution: Information Analysis in the Age of Information OverLoad (2001); David Lew is, InFormation OverLoAd (1999); DAVID SHENK, Data Smog: Surviving the Information Glut (1997); Neil Postman, Technopoly: The Surrender of Culture to Technology (1992); Richard Sam Wurman, Information Anxiety (1989).

6. During a lifetime, most people will devote a full year and one-half to watching commercials. Ronald K.L. Collins \& David Skover, The Death of Discourse 78 (1996). Some observers have estimated that the pornography business in the U.S. generates between $\$ 10$ billion and $\$ 14$ billion annually. See Frank Rich, Naked Greed Succeeds, Orlando Sentinel, July 1, 2001, at G1. It is also estimated that one in four regular Internet users visits a sexually explicit site on the Internet at least once a month. See Clay Calvert, Regulating Sexual Images on the Web: Last Call for Miller Time, But New Issues Remain Untapped, 23 Hastings Comm. \& EnT. L.J. 507, 524 (2001). This number is far more than the number of persons who visit any government-run Internet site. Id. Pornography is a particularly worrisome problem on the Internet, since "[n]inety percent of children between the ages of five and seventeen . . . now use computers." Mitchell P. Goldstein, Congress and the Courts Battle Over the First Amendment: Can the Law Really Protect Children From Pornography on the Internet?, 21 J. MARSHALl J. COMPUTER \& INFO. L. 141,143 (2003). Studies have shown that most adult-oriented commercial web sites do not use age verification measures, and that about a quarter of them employ practices like mouse trapping that keep users from exiting the site. $I d$. at 144 . Moreover, approximately three quarters of them displayed adult content on the first page, which was accessible to everyone. Id. at 145. 
media, such speech is being overproduced in comparison with political speech. $^{7}$

A criticism of television content hardly needs to be repeated here. ${ }^{8}$ In recent years, with sexually exploitive reality shows becoming ever more prominent on the television schedule, critics have bemoaned the continual downward spiral of television programming. Public complaints to the Federal Communications Commission ("FCC") about indecent programming have soared. ${ }^{9}$ Similarly, the Internet, given its wealth of images and information, naturally contains much that is offensive to people - pornography, violence, vulgarity and hate speech. Furthermore, this information does not require as much deliberate or educated action as the courts seem to believe. ${ }^{10}$ For instance, someone who types in www.whitehouse.com (instead of www.whitehouse.gov) is immediately channeled into a pornography web site.

Despite the flood of intrusive and undesirable images and information in today's media, First Amendment scholars keep clamoring for a more open gateway for speech. It is as if speech is already a roaring river, and the scholars want to blow up all the remaining dams. Contrary to what seems to be the assumption underlying the marketplace metaphor, it is not the absence of government censorship that is opening the gates to all this speech; it is the unrelenting march of technology. The growth of the medium is fueling an unsatiable appetite for content, regardless of what the government does or what policies the FCC seems to follow, and what is serving this appetite is what now fills the television schedules, most of which would probably fit the category of "low value" speech. ${ }^{11}$

7. See infra Part VI.E.

8. See David L. Bazelon, FCC Regulation of the Telecommunications Press, 1975 DuKE L.J.213. As Judge David Bazelon has noted, broadcasting is regulated because it is "the most powerful form of communication and methodology for manipulation of human behavior yet known to mankind." Id. at 228 .

9. See FCC's Chief: TV Gets Too Racy, The Cincinnati Post, Nov. 22, 2002, at A2 (quoting FCC Commissioner Michael J. Copps, who claimed that too much indecent speech is getting on the airwaves, and that "too many truly indecent broadcasts are falling through the cracks").

10. See Reno v. ACLU, 521 U.S. 844, 853-55 (1997).

Computer networks, bulletin boards, and electronic e-mail are largely inaccessible to children. These technologies are used overwhelmingly for delivering text, so there is less concern ... that a child ... may see an image ... that is offensive. Moreover ... computerized information is less likely to enter the home "accidentally." Enough affirmative steps must be taken, and sufficient control must be exercised over what information is received, to reduce the chance of surprise by an "indecent" image or sound....

Fred Cate, The First Amendment and the National Information Infrastructure, 30 WAKE ForeST L. REV. 1, 44 (1995).

11. See Vоцокн, supra note 5. "Low value" speech generally includes commercial speech, obscenity and offensive speech. Id. See also Geoffrey Stone et AL., Constitutional Law 1058-1169 
The government, however, cannot act as a quality censor. With few exceptions, it cannot distinguish between "high value" and "low value" speech. Yet that does not mean that abundance should still be the primary First Amendment objective, nor that opening the floodgates ever further is the appropriate response during a time of flood.

\section{B. Control as the First Amendment Imperative}

Is the First Amendment all about turning speech into a torrential river that overpowers everything in its path? Is it all about rendering the listener helpless in the swirling waters? ${ }^{12}$ Is the First Amendment strictly a one-way clause, concerned only with the production of speech? ${ }^{13}$ The traditional response, of course, is that the individual has the power and duty to stop the flood, whenever it becomes overbearing. The individual can simply avert his or her eyes. ${ }^{14}$ He or she can simply pull the plug on the television, disconnect the computer, switch off the radio. At least, that has always been the theory. But is that theory even workable, much less reasonable? Is it reasonable to expect people living in a media society to isolate themselves from the media? Is the First Amendment all about making people avert their eyes until they finally wear out and give up?

No part of American society has changed as much as its media component, and the law must adjust to this change. As Oliver Wendel Holmes

(1986).

12. See Byron Rohrig, No-Call Plaintiff Mulls Options, Evansville Courier \& Press, July 9, 2002 , at B1. In a case in which an Indiana state court judge rejected a constitutional challenge to Indiana's no-call list, circuit court Judge Carl Heldt stated: “Although the First Amendment imposes strict limitations on government actions that interfere with the free exchange of ideas, the First Amendment does not stand as an impediment to private decisions to give audience to certain types of speech while avoiding others." Id.

13. Cf. Kovacs v. Cooper, 336 U.S. 77, 88 (1949). "To enforce freedom of speech in disregard of the rights of others would be harsh and arbitrary in itself." Id.

14. See Erznoznik v. Jacksonville, 422 U.S. 205 (1975) (striking down an ordinance prohibiting drive-in movie theaters from exhibiting nudity). The Court placed the burden of eluding exposure to the speech on the viewer, opining that "the burden . . . falls upon the viewer to . . avert [his] eyes." Id. at 210-11. Similarly, in Cohen v. California, the Court refused to permit censorship of the message "Fuck the Draft" that was printed on the back of a jacket worn in the public corridors of the Los Angeles courthouse, even though passers by would be involuntarily exposed to the message. Cohen v. California, 403 U.S. 15 (1971). And finally, the Court reiterated the principle in United States v. Playboy Entertainment Group, Inc., a case dealing with sexually explicit programming on cable television, where the Court rejected the government's attempted restrictions, holding that those offended by such programming should simply avert their eyes. United States v. Playboy Entm't Group, Inc., 529 U.S. 803, $813(2000)$. 
said: "The life of the law has been experience." 15 In the past, First Amendment doctrines have evolved so as to keep pace with social changes. During the 1960s and 1970s, these doctrines accommodated the changing face of political dissent. Over the past half-century, they have attempted to meet the challenges posed by new communications technologies - first broadcast, then cable television, and now the Internet. ${ }^{16}$ Yet despite all this social change, much First Amendment analysis is premised on an outmoded paradigm: the street corner speaker airing his political opinions. Similarly, censorship has been viewed in a naively one-sided light, with the belief that any censorship will repress the vital democratic dialogue on which our society depends, even though a vast majority of our social speech has nothing at all to do with any issue of genuine public interest. ${ }^{17}$

With respect to the electronic media, much of the First Amendment case law has been based on a concern with scarcity. Spectrum scarcity was what first justified FCC regulation of television, and it continues to influence the courts in cases involving cable television. ${ }^{18}$ Although, with cable, the more pressing concern with scarcity involves a competitive scarcity caused by cable monopolies. ${ }^{19}$ To address this concern for scarcity of voices, the marketplace metaphor was applied. However, lost in all the obsession with scarcity was the reality of what was taking place within America's media. An overload of consumer information and entertainment was drowning out just the kind of political and public affairs dialogue the First Amendment values most. ${ }^{20}$

The First Amendment speech clause is not just about speaking. More fundamentally, it is about individual control and the ability to control one's role within the social commerce of ideas. ${ }^{21}$ The speech clause is not about

15. Oliver Wendell Holmes Jr., The Common Law 1 (1881).

16. See generally Lee C. Bollinger, Images of a Free Press (1991). One aspect of the broadcast model is that it recognizes, as the print model has not, that First Amendment freedoms (as with any other provision of the Constitution) may change with the times.

17. See Playboy Entm't Group, Inc., 529 U.S. at 818. "Were we to give the Government the benefit of the doubt when it attempted to restrict speech, we would risk leaving regulations in place that sought to ... silence dissenting ideas." Id.

18. See Columbia Broad. Sys., Inc. v. Democratic Nat'l Comm., 412 U.S. 94, 101 (1973).

19. See Turner Broad. Sys., Inc. v. FCC, 520 U.S. 180 (1997) [hereinafter Turner II].

20. See Jay Rosen, The Erosion of Public Time, The Quill, Sept. 1991, at 22-23. See also Buckley v. Valeo, 424 U.S. 1, 14 (1976). "The First Amendment affords the broadest protection to . . political expression." Id.

21. See Jerry Berman \& Daniel J. Weitzner, Abundance and User Control: Renewing the Democratic Heart of the First Amendment in the Age of Interactive Media, 104 YALE L.J. 1619, 1620-21 (1995) (making the argument that the way to an open, interactive communication system is through "user control"- giving individuals a right to shut off). 
making sure that every bit of speech can flow unimpeded to every member of the public (as the marketplace metaphor envisions); it is about each person being able to decide what ideas are right for consideration. ${ }^{22}$ Yet the more that media speech becomes ubiquitous, the more power people need to control it. Like water, speech is a vital thing, but not when it floods. So far, though, First Amendment doctrines have barely recognized this flood and the suffocating effects it can have. They have not considered the plight of the individual in a 500-channel world.

In the information age, freedom of speech may well mean the freedom to filter that speech; and a private right of censorship may be needed to give the individual some semblance of control that the First Amendment envisions. Such a right would give the individual the ability to choose, effectively, what speech is to be received and digested. And in the near future, if not already, there may very well be the technology to make such a private right of censorship fully functional.

One of the longest-standing arguments in First Amendment doctrine regards the existence of a hierarchy of speech. On occasions, courts have recognized that not all speech has the same constitutional importance, ${ }^{23}$ but the snag in this recognition is how the hierarchy of speech will be distinguished without invoking the dictatorial hand of government. With a private right of censorship, however, it is the individual who is given the power to block out what is low value speech to him or her. Such a right could

22. Turner Broad. Sys. v. FCC, 512 U.S. 622, 641 (1994) [hereinafter Turner I]. Giving people the ability to decide or control what ideas or information is appropriate for themselves was an underlying goal of the V-chip, which resulted from the Telecommunications Act of 1996, mandating that televisions be equipped with a chip that will permit programs with certain ratings to be blocked from a person's home TV set. 47 U.S.C. $\S 330$ (c)(1)-(4) (2000). In December of 1996, industry lenders announced a ratings system that would be used with the V-chip. Lawrie Mifflin, TV Industry Leaders Unveil Technique of Rating Shows, N.Y. Times, Dec. 20, 1996, at A18. "This development of a ratings system means that the V-chip law will probably not be challenged in court. But if it was challenged, the constitutionality would turn on who establishes the ratings system and who determines the rating for a particular program." Howard M. Wasserman, Second-Best Solutions: The First Amendment, Broadcast Indecency and the V-chip, $91 \mathrm{Nw.}$ U. L. REv. 1190, 1225 (1997).

23. Dun \& Bradstreet Inc. v. Greenmoss Builders, Inc., 472 U.S. 749, 758 (1985). See also supra note 11 and infra note 61 and accompanying text. According to Alexander Meiklejohn, the First Amendment protects only political speech, or speech necessary for the conduct of self-government. See, e.g., Alexander Meiklejohn, Free Speech and Its Relation to Self-Government (1948) [hereinafter Meiklejohn, Free Speech]; Alexander Meiklejohn, Political Freedom: The Constitutional Powers of the People (Oxford Univ. Press 1965) [hereinafter Meiklejohn, Political Freedom]. See generally Connick v. Myers, 461 U.S. 138, 145 (1983) (affirming that "speech on public issues occupies the highest rung of the 'hierarchy of First Amendment values,' and is entitled to special protection") (quoting Carey v. Brown, 447 U.S. 455, 467 (1980)). 
give a fighting chance to the "traditional First Amendment values [of] serious dialogue and civic participation [which] are overshadowed" and often drowned out by the deluge of mass entertainment and consumer advertising. ${ }^{24}$

The existence of a private right to censor may very well allow Congress to require Internet providers to furnish their users with filtering software. It may justify the forcing of television networks to carry outside ratings for their programming so that viewers can effectively exercise their right to censor. Although the First Amendment may not necessarily carry an affirmative right to privately censor, it would clearly not stand in the way if Congress were to enact legislation containing or empowering such a right.

\section{A Private Right to Censor as Protected by the First AMENDMENT}

There has always been a common sense foundation for a private right to censor. Obviously, people do not indiscriminately read or view every bit of speech with which they come in contact. They choose not to read certain books, they refuse to see certain movies, and they deliberately refrain from turning on certain television programs. The Constitution would obviously disallow any law that required people to read, or view, or listen to certain speech; and the courts have frequently reaffirmed the principle that people should be free to choose what they read or view. ${ }^{25}$ But the courts have never explicitly recognized or defined, except in some narrow and isolated circumstances, any right to privately censor. Only in a few cases have they allowed a burden on speech to be justified by anything resembling a private right to censor. ${ }^{26}$ Even then, the decisions have hinged more on privacy concerns than on any individual right to privately censor. ${ }^{27}$ Consequently, the right or ability of a person to censor unwanted speech has been left more or

24. Collins \& SKover, supra note 6 , at 4 .

25. Turner I, supra note 22, at 641. The First Amendment protects against government efforts to choose which information sources are or are not appropriate for any given listener. Id. See also Rowan v. United States Post Office Dep’t, 397 U.S. 728, 738 (1970). "[No]-one has a right to press even 'good' ideas on an unwilling recipient." Id.

26. Cf. Hurley v. Irish-American Gay, Lesbian \& Bisexual Group, 515 U.S. 557, 573-74 (1995) (holding that the First Amendment protects the freedom to create one's own mix of speech), and Miami Herald Publ'g Co. v. Tornillo, 418 U.S. 241, 258 (1974) (ruling that editing is a constitutionally protected function).

27. See Rowan, 397 U.S. at 736 . People have a right "to be let alone," and no one has the right to inflict material upon an unwilling receiver, and nothing in the First Amendment contradicts this basic protection of the sanctity of personal space." See id. at 736-38. 
less in legal limbo. As far as keeping out what speech they do not want, every person is on their own. It is survival of the fittest. Yet to most people, censorship is really the flip-side of speech. It is the way many express their opinions, by rejecting those with which they disagree. It is the speech of the inarticulate. ${ }^{28}$ In an information age experiencing a flood of media speech, censorship may be the only type of speech available to the common person.

Under the First Amendment, most governmental burdens on a person's ability to publicly express themselves are strictly scrutinized. ${ }^{29}$ However, no such scrutiny is given to measures which diminish a person's ability to censor. In fact, it is the opposite treatment that is usually given to any measure resembling a private right to censor, since that measure itself is strictly scrutinized for any adverse effect on the flow of speech. The vast majority of conflicts between the right to speak and the right to privately censor unwanted speech are resolved in favor of the former. Hence, whatever legal recognition has been given to private censorship rights is almost totally without force. ${ }^{30}$

Looking back on constitutional history, there is a strong basis for concluding that the Framers were more comfortable with nongovernmental censorship than with an individual's freedom to engage in offensive or

28. See P.G. Ingram, Censorship and Free Speech: Some Philosophical Bearings 119 (2000). Censorship is "a necessary accompaniment to free speech." Id.

29. See 1 Rodney A. Smolla, Smolla and Nimmer on Freedom of Speech § 4:1 (2003). "The strict scrutiny test is the default standard for measuring the content-based regulation of speech." Id.

30. Only under the captive audience doctrine has there been any real judicial recognition of the unwilling listener; and even then, the rulings have been based more on the kind of speech at issue (e.g., pornography) and the precise physical location of the listener (e.g., walking by a neighborhood porn theater, or commuting to work in a street car). In Lehman v. City of Shaker Heights, the Court invoked the captive audience doctrine in upholding a law which permitted no political or public issue advertising in the city's public transit system. Lehman v. City of Shaker Heights, 418 U.S. 298 (1974). In his concurrence, Justice Douglas argued that "the right of commuters to be free from forced intrusion on their privacy [precluded] the city from transforming its vehicles of public transportation into forums for the dissemination of ideas upon this captive audience." Id. at 307 (Douglas, J., concurring). Earlier, in Public Utilities Commission v. Pollak, Justice Douglas' dissent pressed for recognition of a right to be let alone that would embrace a right to avoid exposure to unwanted messages while riding on public transportation vehicles. Public Utils. Comm'n v. Pollack, 343 U.S. 451, 467-69 (1952) (Douglas, J., dissenting). "The present case involves a form of coercion to make people listen ... [because] in a practical sense they are forced to ride, since this mode of transportation is today essential for many thousands." Id. at 468.

In Young v. American Mini Theaters, Inc., the Court upheld a zoning ordinance that prohibited adult theaters from locating within 500 feet of a residential area, noting that "there is no claim that distributors or exhibitors of adult films are denied access to the market or, conversely, that the viewing public is unable to satisfy its appetite for sexually explicit fare." Young v. Am. Mini Theaters, Inc., 427 U.S. 50, 62 (1976).

But in effect, the captive audience doctrine seems more a recognition of some right of privacy than of any right of private censorship. (Although, in the media society that America has become, there is an argument that the entire public has become a captive audience.). 
sexually explicit speech. $^{31}$ In late eighteenth-century America, where interaction between people was conducted primarily on a face-to-face basis (and certainly not with the anonymity that now prevails on the Internet), censorship was a foregone conclusion. The social mores and customs of the times dictated the nature and content of public speech. Explicit sexual speech was solidly repressed by this code of censorship, as was vulgarity and gratuitous violence. ${ }^{32}$ Consequently, there is every reason to presume that the Framers expected the First Amendment to have no adverse effect on this code of censorship. ${ }^{33}$ In fact, the passage of the Alien and Sedition Acts in 1798 was a recognition that the Framers did not intend that all censorship practices be wiped away. ${ }^{34}$ Thus, historically speaking, it is not censorship with which the First Amendment is concerned, but rather with whom is doing the censoring.

Although courts have upheld censorship rights, they have generally done so only when such censorship is being exercised by speakers. In Denver Area Educational Telecommunications Consortium, Inc. v. FCC, for instance, the Court upheld a federal law permitting cable operators to prohibit programming that it reasonably believed depicted sexual activities in a patently offensive manner. ${ }^{35}$ Even the government has legal rights of censorship, if that censorship is done in the course of subsidizing particular speech activities by private actors. ${ }^{36}$ But the ordinary person, who possesses the least power in the

31. For a discussion of America's historical experience regarding First Amendment issues, see generally Patrick M. Garry, The First Amendment and Freedom of the Press (1986) [hereinafter Garry, The First Amendment]; Leonard W. Levy, Freedom of Speech and Press in Early American History: Legacy of Suppression (Harper Torchbooks ed., Harper \& Row 1963) (1960).

32. See generally Larry D. Eldridge, A Distant Heritage: The Growth of Free Speech in America (1994).

33. David M. Rabban, The Emergence of Modern First Amendment Doctrine, 50 U. CHI. L. Rev. 1205, 1283-1303 (1983).

34. See Levy, supra note 31, at 245-47, 266-67. See generally 2 Alfred H. Kelly \& Winfred A. Harbison, The American Constitution: Its Origins and Developments (1948).

35. Denver Area Educ. Telecomm. Consortium, Inc. v. FCC, 518 U.S. 727 (1996).

36. In Regan v. Taxation With Representation, the Court upheld a provision in the Internal Revenue Code that prohibits tax deductions for charitable contributions made to organizations that attempt to influence legislation. Regan v. Taxation With Rep., 461 U.S. 540 (1983). As Justice Rehnquist explained, Congress had simply chosen not to subsidize lobbying as extensively as it chose to subsidize other activities of charitable organizations. Id. at 550. It did not violate the First Amendment rights of charities merely by refusing to underwrite the exercise of those rights. Id. In National Endowment for the Arts v. Finley, the Court allowed Congress, in its funding of the NEA, to prohibit the agency from awarding grants to any project which failed to meet a decency standard. 524 U.S. 569 (1998). And in Advocates for the Arts v. Thomson, the Governor of New Hampshire vetoed a proposed subsidy for a particularliterary magazine that had published an offensive poem. 532 F.2d 792 (1st Cir. 1976). The First Circuit upheld the veto by noting that decisions on quality were inherent in artistic subsidies and were necessarily subjective. $I d$. at 
communication processes of a media society, has no constitutionally affirmed right to censor intrusive, unwanted speech.

In the past, society never had the technical ability to provide a private right of censorship. However, with devices like the $\mathrm{V}$-Chip, such a right may now be available,$^{37}$ and if Congress enacts legislation which serves this right, it is the argument of this article that the First Amendment would uphold such an enactment.

\section{A Private Right to Censor as a Third Model}

\section{A. Resolving the Conflict Between Print and Broadcast Models}

In Turner I, the Court once again faced the dilemmas of whether to maintain the disparity in First Amendment treatment of the print and broadcast media, and if so, whether to apply the print or broadcast model to cable television. ${ }^{38}$ This case involved the constitutionality of the must-carry rules, which required cable operators to carry the signals of local broadcast stations, if those stations so demanded. In its analysis, the Court affirmed that cable programmers are fully protected by the First Amendment, thereby rejecting the government's argument that the applicable standard for cable was the least protective standard used for broadcasting. ${ }^{39}$ At the same time, a majority of the Court denied the cable industry's contention that must-carry was a form of content regulation requiring the strictest form of scrutiny, as used in the print model. ${ }^{40}$ Because there was no intent to discriminate on the basis of program content, but rather simply to protect the economic viability of

797.

37. Cf. J.M. Balkin, Media Filters, the V-Chip, and the Foundations of Broadcast Regulation, 45 Duke L.J. 1131, 1143 (1996). The V-chip is not only a blocking filter for children, but also a selecting filter for parents. Id. Professor Balkin goes on to discuss the general acceptance of informational filtering in society, such as when book publishers screen manuscripts, bookstores choose books, and magazine editors select articles. Id. "In the Information Age, it seems, power does not rest with those who have access to information. It rests with those who filter it." Id. at 1147.

38. See Turner I, supra note 22, at 637-41. The First Amendment status of cable television has been in a sort of legal limbo ever since City of Los Angeles v. Preferred Communications Inc., when the Court stated that cable possessed First Amendment freedoms, but did not specify the exact nature of those freedoms. City of L.A. v. Preferred Comm., Inc., 476 U.S. 488, 494 (1986).

39. Turner I, supra note 22, at 637-41. This disparity in First Amendment treatment is reflected in Miami Herald Publishing Co. v. Tornillo, 418 U.S. 241 (1974) (conferring the most protective First Amendment status on the print media), and Red Lion Broadcasting Co. v. FCC, 395 U.S. 367 (1969) (granting a much less protective status on broadcasters).

40. Turner I, supra note 22, at 661 . 
broadcast, the Court found that the appropriate standard of review was an intermediate level of scrutiny applicable to content neutral restrictions that impose only an incidental burden on speech. ${ }^{41}$

On remand, the Court in Turner II upheld the must-carry regulations. ${ }^{42}$ The decision ended up largely negating an important implication of Turner I, namely the recognition of First Amendment rights for cable that were closer to the print model than to the broadcast model. Indeed, Turner II "shows a tolerance for speech-relevant regulatory constraints that is not far from the standard of Red Lion, notwithstanding the Court's earlier holding that the Red Lion standard was inapplicable to cable." ${ }^{\prime 3}$ A strong influence in the Court's decision was undoubtedly a recognition of the market power of cable operators, and the fact that most cable systems operate as local monopolies. ${ }^{44}$

As with so many other cases in which the broadcast and print models clashed, the Turner cases pieced together a third model to apply to cable television. Though the Court did not want to place the same kind of content restrictions on cable that exist for broadcast, it nonetheless continued to see a difference between the print and television mediums, and between the impact that each medium had on its audience. Thus, to the disappointment of many free speech advocates, the Court refused to extend the print model to cable television. ${ }^{45}$

41. Id. at 661-62.

42. See Turner II, supra note 19, at 180. But even with the lower standard of scrutiny used in Turner I, the Court found that the government had made insufficient findings of fact concerning the effects of must-carry on the speech of cable programmers, and thus remanded the case for further findings.

The constitutionality of the must-carry rules in Turner II gives strong support for the constitutionality of a "must-rate" system enacted under a private right to censor and which would require television networks or channels to carry program ratings compiled by outside private groups. See R. Polk Wagner, Filters and the First Amendment, 83 MinN. L. Rev. 755, 786-87 (1999). Professor Wagner argues that a rating scheme could be enacted that would look "quite similar on its face to the "content-neutral' provisions given intermediate scrutiny in Turner Broadcasting v. FCC." Id. at 784. The most common arguments against ratings schemes is that either the government would impose it, or speakers would be forced to rate themselves. See Kevin W. Sounders, Electronic Indecency: Protecting Children in the Wake of the Cable and Internet Cases, 46 DRAKE L. REv. 1, 33 (1997). But under the proposal made here, neither objection would apply, since it would be outside, private groups doing the rating.

43. Glen O. Robinson, The Electronic First Amendment: An Essay for the New Age, 47 Duke L.J. 899,935 (1998).

44. Turner I, supra note 22, at 633 . Without the must-carry regulations, the Court saw a substantial likelihood that the "economic viability of free local broadcast television [would] be seriously jeopardized. Id. [Congress] sought to avoid the elimination of broadcast television because ... '[s] uch programming is . . . free to those who own television sets and do not require cable transmission to receive broadcast television signals." Id. at 646 . "[T] he provisions are designed to ... ensure that every individual with a television set can obtain access to free television programming." Id. at 647.

45. See Robinson, supra note 43, at 935. 
For decades, free speech advocates have been pushing for all media technologies to have the same constitutional status as the print medium. In his famous book, Technologies of Freedom, Ithiel Poole argued that media convergence and the democratizing aspects of the new media should bring a convergence of constitutional treatment, and that under the First Amendment all media should be governed by the print model. ${ }^{46}$ Poole's argument, as well as the continued arguments of those pushing for uniform application of the print model to all technologies, hinges on a particularly optimistic view of technology. ${ }^{47}$ The advocates point out, correctly it seems, that the new technologies offer opportunities for a dramatically increased array of viewpoints, and that public access to these technologies is much greater. ${ }^{48}$ They argue, again correctly, that the new technologies render obsolete the old scarcity rationale that once justified broadcast regulation. What they do not talk about is the dark side of these technologies.

While much of their focus is on making cable and other technologies like print, in a regulatory and constitutional sense, they ignore the intrinsic differences in those mediums. ${ }^{49}$ One glance at the pages of a newspaper, compared with the daily line-up in a cable schedule, tells everything about the contrast between print and television. One focuses primarily on news and information, the other on entertainment. One presents its content in print,

46. Ithiel de Sola Pool, Technologies of Freedom (1983).

47. Id. Three decades ago, many of the same predictions made today about the Internet were made about cable television. Americans were told to ready themselves for a communications revolution. See generally Sloan Comm'n on Cable Comm., On The Cable: The Television of Abundance (1971). The Sloan report shows how there were so many hopes for all those channels, and for a whole new communications system. While network television had been homogenizing the country, cable would decentralize it. Network economics required mass audiences, but cable could serve specialized, differentiated audiences. A glorious new content would find a medium: operas, in-depth news programs, book readings. But of course, as Bruce Springsteen's song, " 57 Channels and Nothing On," points out, this rosy future has yet to materialize. And as Professor Branscomb argues, "if we compare the "hype' with which cable television was offered to the public in the early 1970 's" with the current reality, "there is much room for cynicism." Anne Wells Branscomb, Anonymity, Autonomy and Accountability: Challenges to the First Amendment in Cyberspaces, 104 Yale L.J. 1639, 1677 (1995).

48. Jefrrey Abramson et al., The Electronic Commonwealth 46, 57, 12 1-22 (1988).

49. Robert Hughes summarizes the differences between print and broadcast:

TV favors a mentality in which certain things no longer matter particularly: skills like the ability to enjoy a complex argument, for instance, or to perceive nuances, or to keep in mind large amounts of significant information, or to remember today what someone said last month, or to consider strong and carefully argued opinions in defiance of what is conventionally called "balance." Its content lurches between violence of action, emotional hyperbole, and blandness of opinion . . . Commercial TV has come to present society as a pagan circus of freaks, pseudo-heroes, and wild morons .... .

Robert Hughes, Why Watch It, Anyway?, N.Y. Rev. Books, Feb. 16, 1995, at 38. 
requiring a certain level of cognitive deliberation, while the other presents its content in visual images aimed at eliciting an emotional or instinctive reaction. One seems to concentrate on a logical presentation of views and information, while the other seems increasingly obsessed with pushing ever further the bounds of decency and decorum.

The current demands for greater First Amendment protections for the electronic media are grounded in the same kind of optimistic predictions that were made for cable in the $1970 \mathrm{~s} .^{50}$ But few would now claim that cable has lived up to those rosy predictions, and it is questionable whether the Internet will become the forum for democratic dialogue that its defenders claim it will. Therefore, given the differences in content between print and electronic media, and given the different ways in which that content is portrayed, it is reasonable to think that courts will continue to treat the various technologies differently and will continue to search for a third constitutional model to serve as a midway point between the print and broadcast models. It is argued here that this third model is one incorporating a private right to censor.

\section{B. A Private Right to Censor as a Third Model}

In crafting its amorphous, somewhat contradictory third model, the Turner Court realized the problems involved in governmental meddling into content, yet also recognized the intrusiveness of television and its ability to exploit its audience. ${ }^{51}$ However, recognizing a private right to censor would have been a better way of arriving at a First Amendment model to govern cable television. $^{52}$ This model would keep government out of content regulation, yet would enable the viewer to have greater control to combat the unwanted intrusiveness of television. This third model would also eliminate the need for the false and contrived distinctions that courts must make

50. See supra note 47. For glowing predictions on the democratizing and individually enhancing potential of the Internet, see, e.g., Lawrence Lessig, The Zones of Cyberspace, 48 STAN. L. REV. 1403, 1407 (1996).

51. The Court recognized that scarcity was not a rationale for regulating cable as it was for broadcast television, but it also recognized the monopoly power possessed by cable. See supra note 44 .

52. I was wrong in my book, Scrambling for Protection, when I argued for First Amendment convergence for the various types of communications technologies. PATRICK M. GARRY, SCRAMBLING FOR Protection: The New Media and the First Amendment 135-53 (1994). What is so often ignored is that the different technologies have different ways of intruding and delivering unwanted speech or images. Consequently, individuals must have different ways in which to censor or reject those images. While so much focus is put on ending the differing constitutional treatment of television and print, for instance, the reality still remains that television is drastically different from print in both content and the way in which that content is delivered. 
between indecent, lewd, filthy, vulgar and obscene programming, because a private right of censorship would give individuals greater power to make and effectuate such distinctions. Finally, a private right of censorship might address the illusion promulgated under current First Amendment theory that indecent speech is as vital for a functioning democracy as is political speech.

\section{A Bedrock Principle-The Sanctity of the Home}

Within the home, censorship rights are supreme. Within the home, a family's right to censor prevails over anyone else's right to speak. The sanctity of the home has been consistently recognized by courts, ${ }^{53}$ but they have not put any real force into this vague principle of sanctity. In a practical sense, a person's right to censor within his or her own home is subservient to the media's right to speak. While the media possesses many constitutional protections to carry its speech into the home, an individual has very little legal options to censor what she does not want to see or hear.

Of course, as the theory goes, a person always has the ability to turn off the television or disconnect the cable and live a media-free life within the isolated cocoon of his or her home. But is it really feasable, or even desirable, for people to have to live such isolated lives within a media society? ${ }^{54}$ Do people really have the right to censor within their own home if their only choice is to cut off completely the medium which may constitute the only real commonality in a diverse society?

Ideally, technology can make possible a private right of censorship which requires no governmental assistance or intervention. ${ }^{55}$ Ideally, a person could

53. See Rowan v. United States Post Office Dep't, 397 U.S. 728, 736 (1970) (sustaining a statute permitting addressees to prohibit all future mailings from a specified sender); United States v. On Lee, 193 F. 2d 306, 315-16 (2d Cir. 1951) (stating that "[a] sane, decent society must provide some . . oasis, . . . some insulated enclosure, some enclave, some inviolate place which is a man's castle"). The Court in Rowan conceded that the statute undoubtedly impeded the flow of ideas, but held that this effect was subordinate to the right of people in their homes "to be free from sights, sounds, and tangible matter we do not want." Id. at 736 .

54. In a society in which more than seventy percent of all homes have cable television, is it wise to force people outside of this media and communications culture? See Nielsen Media Res., 1998 Report ON TELEVISION 4 (1999). And as Professor Balkin argues, "the point of [the] captive audience doctrine... is that they should not have to be put to such a choice." J.M. Balkin, Free Speech and Hostile Environments, 99 Colum. L. Rev. 2295, 2312 (1999); see infra Part VII.A.

55. See Balkin, supra note 37, at 1150. As Professor Balkin postulates:

[P]erhaps the best [system] would be a pay-per-view system, in which each home could order any available programming at any time of day .... What matters is not the increased number of channels by itself, but the increased number of channels coupled with new ways to block, select, and organize programming. If broadcast media can permit blocking and time-shifting of 
pick and choose not only what television stations or channels she wishes to receive, but even the particular programs on those channels. ${ }^{56}$ If such technology existed, and if Congress mandated that cable carriers provide it, then the constitutionality of such a mandate would depend on whether it served the private right of censorship without an unreasonable hardship on the right to speak. In addition, if Congress mandated cable providers to carry program ratings provided by outside rating groups, such a mandate could also be constitutional under the right of private censor, since it would give individuals a better chance to make informed decisions about what programs not to view. ${ }^{57}$ These measures, under the rule of Turner I, would qualify as content-neutral. ${ }^{58}$

programming easily, cheaply, and painlessly, they will have largely approximated the filtering status of the print media.

Id.

56. See Berman \& Weitzner, supra note 21, at 1633.

In the future, users, instead of the government or network operators, could exercise control with such filtering technology over the information content that they receive in an interactive network environment. User control could be exercised in two ways. First, users could screen out all messages or programs based on information in the header. If a parent wanted to prevent a child from seeing a particular movie or from participating in a particular online discussion group, then the computer or other information appliance used by the child could be set by the parent to screen out the objectionable content. Such features could be protected with passwords assigned, for example, by the responsible adults in the house. Second, the same header information and filtering systems could be used to enable blocking of content based on third-party rating systems. For example, those parents who accept $T V$ Guide's judgment about the presence of nudity and/or violence in particular programs could program their interactive TV sets to screen out all programs that $T V$ Guide has classified as violent. Because of the flexibility of interactive technology, however, we need not rely on just one rating system. ... The Christian Coalition or People for the American Way could set up rating systems that would be available on the network to those who desire them. Rather than relying on the judgment of the government, or of the TV network, viewers could limit access to content based on the judgment of a group whose values they share. Id.

57. $C f$. Meese v. Keene, 481 U.S. 465 (1987). The Court considered the issue of whether the label "political propaganda" placed on a film by the government constituted a First Amendment violation. The Court found that it did not. Id. at 484-85. Thus, the Court approved of this measure that would help educate potential viewers as to the nature of the film's content. The ruling in Meese gives support to a government-mandated ratings or labeling scheme (and particularly if those ratings are provided by private groups). See Wagner, supra note 42, at 781-83, 785. Professor Wagner presents a discussion of various filtering and rating schemes, and the potential benefits they offer. See generally id. at 759-71. For a discussion of ratings systems used on the Internet, see Nachbar, supra note 1, at 220-30.

58. In Turner I, the Court held that the must-carry rules, on their face, "impose burdens and confer benefits without reference to the content of speech." Turner I, supra note 22, at 643. In the Court's view, the regulations were not content-based, since they do not punish or require speech of a particular content. $I d$. at 647. As Professor Sunstein has written, "[t]his holding ... means that Congress will be permitted to regulate particular technologies in particular ways, so long as the regulation is not transparently a subterfuge for a legislative desire to promote particular points of view." Cass Sunstein, The First 
However, in the meantime, technology might not allow individuals such complete power in the choice of programs they wish to exclude from their home. What if individuals cannot make such decisions without some assistance from government? Is government allowed to only act in furtherance of increasing the volume of speech? Can it act in furtherance of facilitating the individual's freedom to filter and choose?

If a private right to censor is recognized, if in a media society private censorship is seen as the speech of those who are not part of the media stream, and if in a culture deluged with speech a right to filter incoming speech is seen as par with a right to add to that deluge of speech, then the courts must give some power to that right. Their vision must not be strictly one-way, focused only on the speaker. ${ }^{59}$ If there is to be a private right to censor, that right must be effective - it cannot be merely theoretical.

Consider, for example, the plight of a conservative religious family. A common charge made against the religiously devout is that they are "out of touch," cut off from the realities of modern culture. Yet, are they to be further cut off just because they do not wish to have television shows like "The Howard Stern Show," or "The Victoria's Secret Fashion Show," or "X-treme Dating" come into their home? Must they completely disconnect the television and be in the minority of those who do not subscribe to cable, just because they do not want to be exposed to what they consider filth? Must they do without CNN and the Discovery Channel and MSNBC just because they do not want their children tuning into a "reality" program in which young men and women are plotting to have sex with people they have only just met, all to win a million dollars?

Perhaps that religious family would subscribe to cable television if they had some means to filter out all the offensive material. If the cable provider was required to carry program ratings from an outside group whose judgment the religious family trusted, perhaps they would feel more comfortable dealing with the flood of programming. Or if the cable provider was made to segregate categories of programming on certain blocks of channels, perhaps the family would feel more at ease surfing through the selections. Would such

Amendment in Cyberspace, 104 YALE L.J. 1757, 1769 (1995).

59. The Red Lion rule permits and even exhorts the government to override broadcasters' programming preferences to effectuate the right of listeners and viewers "to receive suitable access to social, political, esthetic, moral, and other ideas and experience...." Red Lion Broad. Co. v. FCC, 395 U.S. 367, 390 (1969). Thus, the broadcast model focuses on the interests of the listener, but does so with the direct involvement of the government into content. The private right to censor, however, tries to achieve the same goal without this intrusive hand of government. 
measures constitute a burden to the cable company? No question. Would they serve the right of people to exclude unwanted programming from their home? Perhaps. The answer would be up to Congress and the courts to provide - to make sure that such measures did in fact serve a right to censor, and that the burdens inflicted on speech did not pose an absolute bar to that speech. ${ }^{60}$

But ratings carriage and channel segregation are restrictions that affect the conveyance of speech on a society-wide basis, not just to the individual home. Consequently, for these restrictions to pass constitutional muster, they should meet a four-part test. First, the restrictions must be aimed at programming to which children would likely be exposed. Second, the programming must be of a type from which the government has a legitimate interest in shielding children. (Graphic violence and sexually explicit programming would meet this requirement; however, political speech, as outlined in the theories of Alexander Meiklejohn, ${ }^{61}$ would be immune from such restrictions). Third, the restrictions could not amount to a complete ban on speech. (Maybe the Playboy Channel would be confined to a channel number in the eighties, or available only on pay-per-view during after-school hours, but it would still be available to desiring adults). Finally, the restrictions would have to be the least burdensome available, given the legitimate goal they are striving to meet. And as technology advances, making complete program selection possible to individual homes, these restrictions should then be phased out.

60. Such measures would have to comply with the parameters laid down in Young v. American Mini Theaters, 427 U.S. 50, 59 (1976).

61. Alexander Meiklejohn articulated the view that freedom of speech is necessary for intelligent self-governance in a democracy. See generally MeikLejohn, Free SPEech, supra note 23; MeIKLejohn, Political Freedom, supra note 23. Because of this relation between democracy and free speech, Meiklejohn wrote that government could intervene to elevate public discourse, in the same way that the presiding officer of a meeting may enhance the deliberative processes of that meeting. Meiklejohn further wrote that the First Amendment should protect only speech that is related to self-governance ("political speech"). Meiklejohn used the town meeting metaphor, rather than the marketplace metaphor, to explain the First Amendment; and he saw the self-governance rationale as a function distinct from the marketplace of ideas rationale. If self-governance is the whole point of the American experiment, Meiklejohn argued, then freedom of speech must be defined in relation to self-governance. But such a theory has certain consequences. First, speech may be regulated: people may be ruled out of order, on grounds of relevancy. Similarly, people can be forced to observe the house rules of order on matters such as decorum. And finally, not everyone has to speak. If a dozen people share the same opinion, and one person has the opposite view, only two speakers really have to speak. In sum, Meiklejohn argued that the First Amendment only has meaning within the context of the democracy in which it operates, which is not a marketplace free-for-all but a self-governing society with a community of purpose. See generally id. 
Clearly, some measures aimed at effectuating a private right to censor may in turn have a burdensome effect on speech rights. But then, to be effective, the filtering measures have to increase as the power of the speech medium increases; and hence, given the judically-recognized power and intrusiveness of television, any measures giving people the ability to filter out unwanted programming probably cannot be completely burden-free to the media corporations. ${ }^{62}$

Under this private right to censor theory, the general principles of Pacifica Foundation v. FCC should remain the law. ${ }^{63}$ To this day, Pacifica's recognition of the power and intrusiveness of television still rings true ${ }^{64}$ and the Supreme Court has held that cable is closer to broadcast, in terms of its susceptability to regulation, than it is to print. ${ }^{65}$ Moreover, various federal circuit court decisions reflect the parameters set forth above for a private right to censor. In Action for Children's Television v. FCC, the D.C. Circuit upheld the "safe harbor" provisions of the Public Telecommunications Act of 1992, which permit indecent broadcasts only between 10 p.m. and 6 a.m. ${ }^{66}$ (The

62. For a discussion on the judicially-recognized economic power of cable, see Fiss, supra note 3, at $271-74$.

63. In Pacifica, the Court upheld an FCC decision to require broadcasters to channel indecent programming away from times of the day when there is a reasonable risk that children may be in the audience. FCC v. Pacifica Found., 438 U.S. 726 (1978). In relying on the intrusiveness rationale, the Court reaffirmed that broadcasting should receive the most limited of First Amendment protections, since "[p]atently offensive ... indecent material presented over the airwaves" confronts a person in the privacy of the home, "where the individual's right to be left alone plainly outweighs the First Amendment rights of an intruder." Id. at 748-50. Thus, the rights of the public to avoid unwanted speech trump those of the broadcaster. In its decision, the Court reasoned that because the broadcast audience is constantly tuning in and out, prior wamings cannot completely protect the listener or viewer from unexpected program content. $I d$. at $748-49$.

64. See Turner I, supra note 22, at 622. Even in Sable Communications v. FCC, which struck down a ban on dial-a-porn telephone messages, the Court recognized that broadcasting "can intrude on the privacy of the home without prior warning as to program content, and is uniquely accessible to children, even those too young to read." Sable Comm. v. FCC, 492 U.S. 115, 127 (1989).

65. In Turner I, the Court did not analyze the must-carry regulations under a strict scrutiny, but rather with an intermediate scrutiny. Turner I, supra note 22, at 639. And in Turner II, Justice Breyer, in evaluating the regulations, recognized that occasionally some speech has to be restricted in order to further other speech and that only a reasonable balance had to be achieved between the speech-restricting and speech-enhancing elements. Turner II, supra note 19, at 227 (Breyer, J., concurring). Justice Breyer justified compromising cable operators' speech interests to further those of listeners on the economic power of cable operators, who face "little competition" and can constitute "a kind of bottleneck that controls the range of viewer choice." Id. at 228-29.

66. Action for Children's Television v. FCC, 58 F.3d 654 (D.C. Cir. 1995). In Actionfor Children 's Television v. FCC (ACT III), the court emphasized FCC findings about the prevalence of homes in which children had radios or televisions in their own rooms to show that real parental control was impossible. Id. at 661 . 
concept of safe harbor, or the old family viewing hour, are measures that most likely meet the four-part test outlined above). And in Dial Information Svcs. v. Thornburgh and Information Providers' Coalition v. FCC, the courts upheld congressional efforts to place restrictions on "dial-a-porn" services. ${ }^{67}$

Adopting a private right to censor, one can argue that Denver Area Educational Telecommunications Consortium, Inc. v. FCC (the segregate-andblock part) was decided wrongly. ${ }^{68}$ The restrictions in that case meet the fourpart test and do not serve as a complete ban on the subject speech. The Court, however, was singularly focused on the inconveniences to would-be viewers of indecent programming. But television is not the only medium subject to a private right to censor. The Internet, contrary to most pronouncements, can

67. In Dial Information Services v. Thornburgh and Information Providers' Coalition v. FCC the Second and Ninth Circuits ruled that the restrictions in the so-called "Helms Amendment," 47 U.S.C. $\S \S 223$ (b) et seq., did not violate the First Amendment. Dial Info. Svcs. v. Thornburgh, 938 F. 2d 1535 (2d Cir. 1991); Info. Providers' Coalition v. FCC, 928 F.2d 866 (9th Cir. 1991). The rules promulgated pursuant to the Helms Amendment-requiring telephone companies to block all access to dial-a-porn services unless telephone subscribers submit written requests to unblock them, or scramble their messages and sellpersonal decoders - were enacted in response to the Supreme Court decision in Sable striking down a complete ban on dial-a-porn services. One of the most important factors which led the courts in Dial Information Services and Information Providers to rule as they did was the fact that the restrictions did not amount to a complete bar to the indecent speech.

68. See Denver Area Educ. Telecomm. Consortium, Inc. v. FCC, 518 U.S. 727 (1996). At issue in Denver Area were regulations in the Cable Act of 1992 requiring cable operators to place indecent programs on a separate channel, to block that channel, and to unblock it within thirty days of a subscriber's written request for access. $I d$. In addition to imposing the above restrictions, the regulations required the programmers of leased channels to alert cable operators of their intent to broadcast indecent material at least thirty days before the scheduled broadcast date. The Supreme Court held this scheme unconstitutional. Id. The Court, in its decision, was concerned with inconveniences and burdens to would-be viewers of indecent programming, including, for instance, the viewer who might want a single show, as opposed to the entire channel, or the viewer who might want to choose a channel without any advance planning (the "surfer"), or the one who worries about the danger to his reputation that might result if he makes a written request to subscribe to the channel. $I d$. at 754 . And yet, none of these burdens presented insurmountable obstacles. Each one of these types of viewers could get access to the desired programming by simply following the established procedures. Furthermore, even though the Court recognized that the purpose of the regulations was to protect minors, that it was a compelling purpose, and that the regulations only applied to sexual material (and not the kind of information present in the Pentagon Papers case (New York Times Co. v. United States, 403 U.S. 713 (1971)), the Court still struck them down, focusing instead on the provisions' adverse impact on the programming available to adults. Denver Area, 518 U.S. at $755-59$. In doing so, the Court affirmed the principle of Butler v. Michigan, in that the Constitution does not permit the state to reduce the material available to adults to the level of what is appropriate for children. Butler v. Michigan, 352 U.S. 380, 383 (1957). The Court followed this principle even though, in terms of relative burdens, it may be easier for adults to access indecent material than it is for parents to have their children avoid it. And even though the Court, as it did in Pacifica, acknowledged the invasive nature of television, it refused to let this feature justify the regulations. Denver Area, 518 U.S. at 744-45. 
also be intrusive in terms of the unwanted speech to which it can expose children.

Unquestionably, the Internet is a democratizing medium, offering anyone with a computer the ability to speak and share her opinions. It permits direct communication, without the intermediaries of journalists or editors, but is also capable of conveying an almost unlimited amount of hate, pornography, violence and vulgarity. ${ }^{69}$

In Reno v. ACLU, the Court was presented with the question of whether the Internet was to be treated, in a First Amendment sense, like broadcast or print. $^{70}$ In deciding upon the latter standard, the Court analyzed in depth the characteristics of the Internet. It found that the Internet was radically different from the way the Court had viewed broadcast television in Pacifica. There was no intrusiveness problem; users "seldom encounter[ed]" sexually explicit speech accidentally and a "child required some sophistication and some ability to read to retrieve material and thereby use the Internet unattended." ${ }^{\prime \prime 1}$ Given these characteristics, there would obviously be little reason to create any private right to censor protections. But the six years of experience with the Internet since Reno have brought all those assumptions of the Court into doubt.

Contrary to the Court's assumptions, it is not difficult or complicated for children to $\log$ on to the Internet. Nor is it difficult to find sites dedicated to pornography and violence. ${ }^{72}$ Even if a person did not go looking for those sites, they would find them anyway. Pop-up advertisements alert the user to such sites, inviting access through just a click of the mouse. A user might also end up in one of those sites accidentally. A slight mistype, "www.whitehouse.com" (instead of www.whitehouse.gov) will put the user into a pornography site. Unlike many of the early predictions of the Internet,

69. Reno v. ACLU, 521 U.S. at 844,863 (1997).

70. Id. at 868-70. The case involved a challenge to provisions in the Communications Decency Act of 1996 which prohibited the transmission of indec ent messages over the Internet to anyone under eighteen years of age. See generally Reno, 521 U.S. 344.

71. Id. at 854. On the other hand, the Court did find that "sexually explicit material on the Internet ... 'extend[ed] from the modestly titillating to the hardest-core,"” and that this material could be accessed "unintentionally during the course of an imprecise search." Id. at 853. For their part, "[n]ew technologies ... have greatly expanded the opportunity to communicate obscene, libelous, violent, or harassing messages ...." Sunstein, supra note 58, at 1799. And the Internet does contain pornography accessible to children, some of it coming from adults explicitly seeking sexual relations with children. Id. at 1801 .

72. United States v. Am. Library Ass'n, 539 U.S. 194, 123 S. Ct. 2297, 2301 (2003). 
it is not used primarily for delivering text, thus posing more of a temptation to children. ${ }^{73}$

The Internet is also not a replica of eighteenth century town meetings, in which people could share and debate opinions. One big difference with the Internet is its anonymity feature. ${ }^{74}$ Speech can take on an entirely different character when it is being conducted anonymously, and it can more easily lead to the dangers of stalking, deception and manipulation. During the eighteenth century, taking public responsibility for one's speech necessarily imposed some constraints on that speech. ${ }^{75}$ A sort of social custom and decorum served to censor out the more violent or crude statements. Today, with the Internet, there is no social custom available. There is nothing except for the user's own ability to censor unwanted or offensive speech.

In Reno, the Court agreed that there is "a compelling interest in protecting the physical and psychological well-being of minors, which extended to

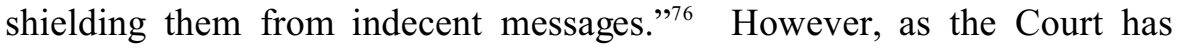
previously done on many occasions, it downgraded this interest when it conflicted with the rights of adults to access such messages burden free. ${ }^{77}$ When it comes to burdens, the Court skews the balance all the way over to the right-to-exclude end of the scale and away from the right-to-receive end regardless of the type of speech, as long as it does not fall into one of the few "low value" categories warranting a lesser First Amendment protection. ${ }^{78}$

73. See Cate, supra note 10 , at 35-36.

74. Critics view anonymity as a threat to accountability and civility on the internet. See Branscomb, supra note 47, at 1659-61. In the 104th Congress, Senator Jim Exon introduced a bill to prohibit anonymous messages "with the intent to annoy, abuse, threaten, or harass any person ... who receives the communication." Communications Decency Act of 1995, S. 314, 104th Cong. § 2(a)(1)(B) (1995).

75. See Steven Botein, Printers and the American Revolution, in THe Press AND the AMERICAN Revolution (Bernard Bailyn \& John B. Hench eds.) 11, 21-22, 32, 37-40 (1980). See generally E. EMERY et Al., The Press and America 8th ed. (1996); Arthur M. Schlesinger, Prelude to Independence (1958).

76. Reno, 521 U.S. at 869 . And this interest cannot be served simply by relying upon parental supervision. See Nachbar, supra note 1, at 220-21. As Professor Nachbar notes, "very few parents have the time to supervise all of the time that their children spend on the Internet." Id. at 220. Nor is parental monitoring "a real alternative for families in which both parents must, or choose, to work, or for those headed by a single parent." Id. Furthermore, "unless the parent were, for example, to open each [web] page with the child looking away and only allow the child to view the page after a parental preview, there is no way to keep the child from taking in the content while the parent is evaluating its appropriateness." $I d$. at 221.

77. Reno, 521 U.S. at 875.

78. The Reno decision, however, might also be explained by the fact that the Court found that there were no effective or feasible filtering mechanisms that could be used on the Internet. Id. at 876, 881 . 


\section{A Rethinking of Burdens}

Traditional First Amendment analysis focuses on the possible burdens that any governmental regulation might place on speech. In United States $v$. Playboy Entertainment Group, Inc., regulations confining indecent cable programming to the hours of 10:00 p.m. to 6:00 a.m. were held to be an unconstitutional burden on adults who wanted to view such programming. ${ }^{79}$ However, the impact on potential viewers was the only side of the speech equation at which the Court really looked. It did not, other than with assumptions, consider any burden to a parent's private right to censor such material if the regulations were struck down. Instead, the Court simply stated that it was the duty of the listener to "avert their eyes." burden was placed entirely on those wishing to exercise their private right to censor within their own home.

The growth of the media society, and the corresponding explosion of media speech, have made the burdens of "averting one's eyes" ever more onorous. Likewise, the demise of social customs which once imposed a sort of unofficial censorship on offensive speech have put even more burdens on "averting one's eyes," to the point where it may be nearly impossible to avoid offensive speech. This imbalance of burdens has been a natural result of the marketplace metaphor, which focuses only on increasing the amount of social speech. But during an age of abundant speech, it is time to reconsider this dramatic inequality between burdens.

The judicial striving for a burden-free environment regarding access to speech not only makes private censorship nearly impossible, but also contradicts the experience of the constitutional period. During the late eighteenth century, people did not have immediate and unconstricted access to social speech. ${ }^{81}$ They had to go to the public houses to read the pamphlets and newspapers. They had to gather in town squares to listen to public speakers. They had to congregate when ships sailed into the harbor. They had to expend great effort to receive their news and political opinions. Social speech was not like a faucet that could be turned on and off whenever the urge hit; it was not like the raging flood that it is today.

79. United States v. Playboy Entm't Group, Inc., 529 U.S. 803, $817-18$ (2000).

80. Id. at 813 .

81. See generally Thomas C. Leonard, The Power of the Press: The Birth of American Political Reporting (1986); Garry, The First Amendment, supra note 31; Patrick M. Garry, The American Vision of a Free Press (1990) [hereinafter Garry, American Vision]. 
It is a perversion of the First Amendment to think of freedom of speech as a flooding of speech. It is a mistake to think of free speech as effortless, automatic speech. It is a violation of people's speech and privacy rights to make parents disconnect their television just so that other adults do not have to wait until ten o'clock to watch the Playboy Channel. ${ }^{82}$ Adults have an almost unlimited access to indecent speech: adult video and book stores, adult theaters, adult mail-order outlets, dial-a-porn telephone services, and Internet porn sites. To limit a cable channel's indecent programming to certain hours of the day poses relatively minute burdens on an adult's ability to receive indecent speech, while greatly aiding a family's private right to censor.

Under the marketplace model of the First Amendment, the parents and children bore all the burdens regarding unwanted speech. However, except in the case of political speech, a private right to censor seeks to achieve an equalizing of those burdens. Adopting a First Amendment model containing a private right to censor does not mean that indecent speech will be suddenly cut off. It means that certain dams may be built to convert wild rapids of speech into a more controlled flow. There may be some burdens or effort needed to access indecent speech, but it will still be available. The recent Supreme Court decision in United States v. American Library Ass ' $n$ illustrates a more balanced placement of burdens. ${ }^{83}$ At issue in that case was a provision in the Children's Internet Protection Act ("CIPA") that required public libraries, in return for federal funds, to install software that would block computer users from accessing pornographic speech or images on the internet. ${ }^{84}$ Congress had passed the CIPA to address problems associated with the availability of Internet pornography in public libraries. ${ }^{85}$ In its decision, the Court stated that "there is ... an enormous amount of pornography on the Internet, much of which is easily obtained." material, according to the Court, "has created serious problems for libraries, which have found that patrons of all ages, including minors, regularly search for online pornography." ${ }^{\prime 7}$ Furthermore, "[s]ome patrons also expose others to pornographic images by leaving them displayed on Internet terminals or printed at library printers." ${ }^{\prime 8}$ This same conclusion had been reached by

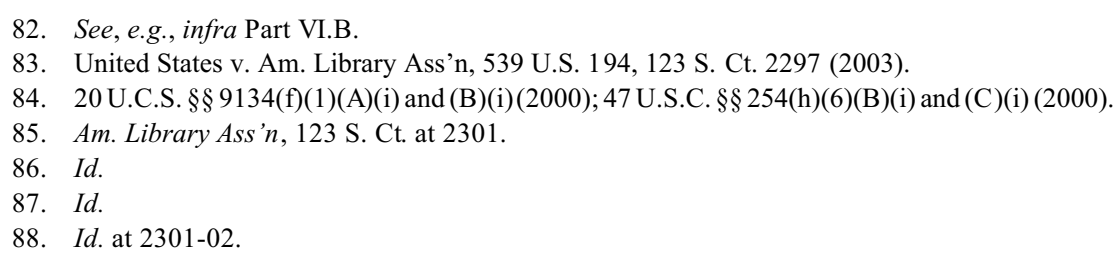


Congress, finding that adults "us[e] library computers to access pornography that is then exposed to staff, passersby, and children," and that "minors acces[s] child and adult pornography in libraries." ${ }^{89}$ Congress had also concluded that filtering software which blocks access to pornographic web sites could provide a reasonably effective way to prevent such uses of library resources.

In upholding the CIPA, the Court ruled that the law did not constitute a complete bar or prior restraint to patrons' access to pornography. ${ }^{90}$ When a patron encountered a blocked site, he or she only needed to ask a librarian to unblock it or, if the patron was an adult, disable the filter altogether, ${ }^{91}$ and a patron would not have to give his or her reasons for requesting a site to be unblocked or the filtering to be disabled. The opponents of the CIPA argued that these procedures placed an unconstitutional burden on the speech rights of adults, because "some patrons might be too embarrassed to request them." However, the Supreme Court found otherwise: "[T] he Constitution does not guarantee the right to acquire information at a public library without any risk of embarrassment." ${ }^{, 93}$

This decision, in its rational look at the relative burdens involved, followed the parameters of a private right to censor. In doing so, the Court bucked the trend followed in Reno and Playboy Entertainment, in which just about any burden on an adult's access to indecent speech, no matter what the risk to children, was seen as reducing the adult population to reading only what is fit for children. In American Library Ass'n, the goal of protecting children from unwanted speech, while allowing them access to the wealth of information on the Internet, overshadowed the small burden on adults who could still view their pornography with just a request to the librarian. It was a decision that finally elevated the filtering rights of parents above a mere interest that always gets shoved aside in First Amendment jurisprudence. It was also a decision taking a step toward a First Amendment model recognizing the private right to censor in a media society.

Under the marketplace metaphor, courts dealing with free speech issues have traditionally required an opt-out scheme rather than an opt-in one. ${ }^{94}$

89. Id. at 2302 .

90. Id. at 2300 .

91. Id. at 2306; 20 U.S.C.A. § 9134(f)(3) (West Supp. 2003); 47 U.S.C. § 254(h)(6)(D) (2000).

92. Am. Library Ass'n, 123 S. Ct. at 2307.

93. Id.

94. The ruling in Reno v. $A C L U$ was consistent with this pattern, holding that government may not require listeners to opt-in to speech that is deemed offensive by the majority when individual opt-out is feasible. See Reno v. ACLU, 521 U.S. 844, 879 (1997); see also Cohen v. California, 403 U.S. 15, 21 
Unwilling listeners must opt-out of the unwanted speech environment. The burden is on them to leave, to extricate themselves. They must either constantly monitor their children on the Internet, or else they must pull the plug. They have to hope and pray as they surf through the cable channels, or else they must disconnect the television. But under a private right to censor, an opt-in requirement is imposed on certain kinds of "low value" speech in an effort to balance the burdens. If an adult wishes to view indecent programming, he or she must make some effort to opt into it, to access it with some personal identification number, or to subscribe to a special channel. With such an opt-in requirement for indecent speech, especially given the pervasiveness of it in a media society, there is no decrease in the amount of speech in the system, just a step required before accessing it.

\section{Values Served by a Private Right to Censor}

\section{A. Selectivity in a Media World}

The more speech that floods society, the more selective people need to be in processing that speech. If information is to be part of a deliberative and cognitive process, which was surely an intent behind the framers' protection of free speech, then people have to have the ability to be selective in choosing what information to receive and contemplate. ${ }^{95}$ A private right to censor will

(1971) (holding that, in the public square, listeners are presumed able to avert their eyes and ears from speech they find offensive and move on); Lamont v. Postmaster Gen., 381 U.S. 301, 305 (1965) (holding that the government may not screen out potential politically offensive materials in advance and require potential recipients to opt-in); Bolger v. Youngs Drug Prods. Corp., 463 U.S. 60, 61-62 (1983) (holding that the federal government could not ban the unsolicited mailing of contraceptive ads-a law which required opt-in).

In its First Amendment decisions, the Court has taken the position that the First Amendment requires opt-out. Yet, the Court has never examined precisely how feasible it is for unwilling viewers or listeners to opt-out, certainly not in the same way that it has examined all the potential burdens placed on those wishing to opt-in. Furthermore, making opting-out even more difficult, the government cannot zone cyberspace - certainly not as it can do when restricting adult theaters to a red light district or requiring adult magazines to be sold in plain brown wrappers. Reno, 521 U.S. at 867-68. But to answer this problem, Justice Stevens noted in his opinion in Reno that there is another alternative to zoning in cyberspace - that listeners can build their own fences at their end, with gates permitting them to screen offensive speech out. Id. at 877-79. But this contains an unwarranted presumption. How many people have access to effective filtering software? And just how effective is that software? And how easily is it disabled? The courts have not factually explored these presumptions. Instead, they presume that opt-in software - software that would embargo transmission of indecent speech unless the user provided a digitized adult identification signal - is so much more burdensome than opt-out software. Indeed, one of the main arguments of the plaintiffs in American Library Ass' $n$ was the ineffectiveness of current filtering systems. 123 S. Ct. at 2302.

95. See Sunstein, supra note 58, at 1762-63. As Professor Sunstein notes, 
help people to be more than just inert consumers of media speech. It will assist them in becoming active participants in the social communication process. As Justice Brandeis once warned, "the greatest menace to freedom is an inert people. ${ }^{~} 96$

If anything, the media age has shown the fallacy of the marketplace metaphor's singular concern with abundance. It is like the old criticism against the nuclear arms race: what does it matter how many times the world can be blown up? Nor has the abundance automatically led to a more informed and analytical citizenry, nor to a greater diversity of viewpoints. ${ }^{97}$ On the eighty or so basic cable channels that exist today, there is less speech reflecting religious values than there was on three channels forty years ago.

\section{B. The Privacy Argument}

Not surprisingly, privacy complaints have abounded in the information age. ${ }^{98}$ Credit card companies and health care providers have been restricted in their speech rights regarding customers and patients. ${ }^{99}$ Telemarketers have come under intense scrutiny from a public who is weary of having their privacy invaded. ${ }^{100}$ Throughout society, there is a growing desire to create a privacy zone free of media intrusion, especially of media speech that pierces into the most personal areas of human life.

[t]here is no logical . . connection between a well-functioning system of free expression and limitless broadcasting or internet options .... It is foreseeable that free markets in communications will be a mixed blessing. The could create a kind of accelerating 'race to the bottom,' in which many or most people see low-quality programming involving trumped-up scandals or sensationalistic anecdotes calling for little in terms of quality or quantity of attention.

Id. at 1763. The process of selectivity was also expressly recognized in American Library Ass'n, $123 \mathrm{~S}$. Ct. at 2304. "The librarian's responsibility ... is to separate out the old from the garbage, not to preserve everything.... A hypothetical collection of everything that has been produced is not only of dubious value, but actually detrimental to users trying to find what they want to find and really need." Id. (citations omitted).

96. Geoffrey R. Stone et Al., The First Amendment 490 (1999).

97. This is not unlike the view that any "children's program," no matter how bad, is more likely than not to be better than the alternatives. But true quality comes from a program's substance, not its topic or category. See Henry J. Friendly, The Federal Administrative Agencies: The Need for Better Definition of Standards, 75 HARV. L. REV. 1055, 1071 (1962).

98. See, e.g., Schwartz, supra note 1, at 1611-13 \& n.8.

99. See generally James P. Nehf, Recognizing the Societal Value in Information Privacy, 78 WASH. L. ReV. 1 (2003); Rebecca H. Bishop, The Final Patient Privacy Regulations Under the Health Insurance Portability and Accountability Act_Promoting Patient Privacy or Public Confusion, 37 Ga. L. Rev. 723 (2003).

100. See infra notes $145-47$ and accompanying text. 
The evolution of American constitutional rights of privacy has occurred primarily in the area of human sexuality. Griswold v. Connecticut ${ }^{101}$ involved the right to use contraceptives; Roe v. Wade ${ }^{102}$ involved the right to an abortion; and Lawrence v. Texas ${ }^{103}$ involved the right to engage in homosexual sex. Under the law, people have a right to develop and practice their own sexuality in private, without the intervention of others. And yet, given the prevalence of sex in today's media, and particularly of "reality" sex among young people, children and adolescents who are exposed to such images and attitudes are having their sexual development, perhaps the most personal area of human development, shaped by an anonymous media. ${ }^{104}$ Parents may make an arduous effort to instill certain sexual or religious values in their children, and yet everyday those values can be belittled in the media. In a culture so dominated by the mass media, in which speech is more the selling of images than the examination of ideas, a private right to censor is needed just to protect the individual from all the ways in which his or her privacy is threatened and invaded.

An individual's right to privacy from the unwanted intrusion of speech, even when that individual is in a public venue, was recognized by the Supreme Court in Hill v. Colorado. ${ }^{105}$ In Hill, the Court upheld a Colorado statute which prohibited anyone from coming within eight feet of another person outside of an abortion clinic, and without that person's consent, for the purpose of passing out a leaflet or engaging in oral protest or counseling. ${ }^{106}$ The Court found that the statute was content-neutral, even though the law was aimed at abortion protestors and even though recognizing that the law imposed burdens on protestors wishing to speak to people entering or leaving the clinic. ${ }^{107}$ The Court also found that the protestors' speech was protected by the First Amendment, and that the public sidewalks covered by the statute were "quintessential" public forums for free speech. ${ }^{108}$ Yet the Court noted that "[i]t is also important ... to recognize the significant difference between state restrictions on a speaker's right to address a willing audience and those that protect listeners from unwanted communication." 109 The Court then went

101. Griswold v. Connecticut, 381 U.S. 479, 480 (1965).

102. Roe v. Wade, 410 U.S. 113, 116 (1973).

103. Lawrence v. Texas, 123 S. Ct. 2472, 2475 (2003).

104. See InGRAM, supra note 28 , at 109.

105. Hill v. Colorado, 530 U.S. 703, 734-35 (2000).

106. Id. at 707 .

107. Id. at 723,726 .

108. Id. at 715 .

109. Id. at $715-16$. 
on to cite a line of case law recognizing "the right to be let alone." ${ }^{110}$ It interpreted this case law as "repeatedly recogniz[ing] the interests of unwilling listeners in situations where "the degree of captivity makes it impractical for the unwilling viewer ... to avoid exposure." 111

The dissent argued that "the right to be let alone" was a right that was only "conferred, as against the government," and not as against private protestors. ${ }^{12}$ The dissent further went on to argue that the speech burdens imposed on the protestors were significant. ${ }^{113}$ Eight feet is not a normal conversational distance, the dissent claimed, especially when the goal is not to protest but to engage in counseling and educating, activities that cannot be done at a distance and at a high decibel level. ${ }^{114}$ The availability of bullhorns and loudspeakers, as the majority proposed, would be of "little help to the woman who hopes to forge, in the last moments before another of her sex is to have an abortion, a bond of concern and intimacy that might enable her to persuade the woman to change her mind and heart."115 Furthermore, the dissent argued, "it does not take a veteran labor organizer to recognize ... that leafletting will be rendered utterly ineffectual by a requirement that the leafletter obtain from each subject permission to approach.... That simply is not how it is done, and the Court knows it." 116

As the dissent in Hill points out, the burdens on speech caused by the Colorado statute were significant. Yet, the Court ruled in favor of the privacy interests of people in a public place wishing to be shielded from the speech of other individuals. Thus, under the holding in Hill, it cannot be said that the burdens caused by a private right to censor are automatically unconstitutional.

\section{The Bickel Argument}

Alexander Bickel wrote that speech was only free in a democracy if it was conducted within certain bounds of civility. ${ }^{117}$ For instance, Bickel argued

110. Id. at 716-17 (citing Olmstead v. United States, 277 U.S. 438, 478 (1928) (Brandeis, J., dissenting); Rowan v. United States Post Office Dep't, 397 U.S. 728, 738 (1970); and Frisby v. Schultz, 487 U.S. 474,485 (1988)).

111. Hill, 530 U.S. at 718.

112. Id. at 751 (Scalia, J., dissenting) (emphasis added) (quoting Olmstead v. United States, 277 U.S. $438,478(1928))$.

113. Id. at 756 (Scalia, J., dissenting)

114. Id. at $756-57$.

115. Id. at 757 .

116. Id. at $757-58$.

117. See generally Alexander M. Bickel, The Morality of Consent (1975). 
that control of obscenity was a matter of public decorum and social environment, completely distinct from subjective morality. ${ }^{118}$ This decorum argument was undoubtedly a foregone conclusion with the framers: that all public speech, even if free from government restraint, would be expressed within the parameters of respect, civility and decorum, and that the First Amendment was in no way aimed at erasing these customs. ${ }^{119}$

There is criticism today that the media has abandoned any adherence to respect, civility and decorum in its speech. Since the media plays such a strong role in defining culture and society, individuals should have a correspondingly strong role in shaping and influencing that media. With a private right to censor, individuals will have a better ability to do so. That, after all, is the premise of democracy.

Bickel recognized a natural, and to some extent necessary, tension between censorship and free speech. "A law attempting to regulate obscenity, [for instance], has to exist in a peculiar tension." ${ }^{20}$ On one hand, "[i]t must avoid tyrannical enforcement of supposed majority tastes"; but on the other, it must provide some visible support for the desire of a democratic community to sustain "the style and quality of life minimally congenial to them."121 Though censorship laws are unable to resolve this tension, a private right to censor belonging to each individual may be able to do so.

When Alexander Bickel wrote, he was observing the breakdown of many social customs that formerly served as a kind of unofficial cultural censor, imposing a framework of civility on public speech. Now that those customs have been nearly obliterated by the mass media, something stronger than occasional laments by media critics is needed, something akin to a private right to censor, belonging to every member of society.

\section{The Media's Inability to Police Itself}

Despite token gestures, the television industry has shown an appalling inability to regulate itself. ${ }^{122}$ Sexual content and graphic violence and vulgar

\section{Id. at 73-74.}

119. See supra notes 72 and 73 and accompanying text.

120. BICKEL, supra note 117 , at 75 .

121. $I d$.

122. Government supervision of broadcasters' programming is essential because, as stated in Red Lion, "[i]t is the right of the viewers and listeners, not the right of the broadcasters, which is paramount." Red Lion Broad. Co. v. FCC, 395 U.S. 367, 390 (1969). Many critics have predicted, and concluded, that if broadcasters were left to their own discretion, they would pander to the lowest common denominator, decreasing the quality of important information while simultaneously increasing commercialization. See 
language are more prevalent than ever before. The vast majority of "reality television shows," like the "Anna Nicole Smith Show," are sliding down to the Jerry Springer level-shows that pay homage to the trinity of sexual shock, defiance, and an "in-your-face" attitude. With shows like "The Bachelor" and "Victoria's Secret Fashion Show," television offends both the radical feminists and the religious conservatives. ${ }^{123}$ Yet, despite this offensiveness, the FCC has been totally inept in overseeing the television industry. Indeed, a glance back at the television standards promulgated by the FCC in 1960 shows just how poorly the Commission has been in maintaining its once minimum expectations of television quality. ${ }^{124}$ Not surprisingly, last year almost 500 complaints were made to the FCC regarding indecent television programming. ${ }^{125}$

There is wide agreement among mass media scholars that television programming is not only addictive, but is designed to be addictive. ${ }^{126}$ There

Public Interest in Broadcasting: Hearings Before the Subcomm. on Telecomm. and Fin. of the House Comm. on Energy and Commerce, 102d Cong. 117-18 (1991). Despite presidential calls for the electronic media to regulate itself (President William J. Clinton \& Vice President Albert Gore, Jr., A Framework for Global Electronic Commerce 18 (1997)), the Federal Trade Commission has reported that such self-regulation has not been successful. See, e.g., Fed. Trade Comm'n, Privacy Online: A Report to Congress 41 (1998). See also Angela J. Campbell, Self-Regulation and the Media, 51 Fed. Comm. L.J. 711, 717-19 (1999) (discussing the criticisms of media self-regulation).

123. Fox News, Watchdog Groups Protest Victoria's Secret Show, at http://www.foxnews.com/story/ 035667090400.html (last visited Nov. 20, 2003).

124. There was a time when the FCC gave precise guidelines to broadcasters about their public interest obligations. The most detailed were contained in the En Banc Programming Inquiry, 44 F.C.C. 2303 (1960). In this statement, the FCC identified a list of program categories that it considered to be part of a balanced portfolio of programming, including: 1) “opportunity for local self-expression," 2) "programs for children," 3) "religious programs," 4) "educational programs," 5) "public affairs programs," 6) "editorializing by licensees," 7) "political broadcasts," 8) "agricultural programs," 9) "news programs." $I d$. at 2314. But this list now seems largely irrelevant. The FCC no longer requires from licensees, as it once did, a detailed specification of program types and the amount of time devoted to each. The only program information currently required on licensee renewal forms is a summary of programming devoted to the educational needs of children. Children's programming continues to be regulated pursuant to Congress's mandate in the Children's Television Act of 1990, Pub. L. No. 101-437, 104 Stat. 996 (codified as amended in scattered sections of 47 U.S.C.).

The initial FCC rules and guidelines were also designed to suppress music that glorified drug use, to suppress dirty words and discussions of sex, to limit commercials, and to increase educational programming that children should watch. See Thomas G. Krattenmaker \& Lucas A. Powe, Jr., Regulating Broadcast Programming 61-136 (1994).

125. See supra note 9 .

126. See Impact of Television on Children: Hearing Before the Subcomm. on Communications of the S. Comm. on Commerce, 94th Cong. 3 (1976); Social/Behavioral Effects of Violence on Television: Hearing Before the Subcomm. on Telecomm. Consumer Prot., and Fin. of the House Comm. on Energy and Commerce, 97th Cong. 11 (1981). See generally Jeanne Albronda Heaton \& Nona Leigh Wilson, Tuning in Troub le: Talk TV's Destructive Impact on Mental Health (1995); Ingram, supra note 
is also wide agreement as to the subliminally manipulative effects of television. Indeed, if it did not have the First Amendment, the television industry, like the tobacco industry, would be swamped with product liability lawsuits.

One way to regulate television without governmental dictatorship of content is through a private right to censor. Perhaps if the burden was shifted more toward opting-in to television versus opting-out, people could make more rational decisions regarding their viewership. Sitting down at the kitchen table, in the middle of the day, studying the schedule of television programming, might lead to a more rational and disciplined decision regarding viewership than plopping down into an easy chair at night, when the mind is tired from a day of work and all too ready to fall into whatever mind-numbing show is being offered on TV. However, by recognizing a private right to censor, the courts might help the public break out of the hypnotic trance in which television hopes to keep them.

\section{E. Aiding the Democratic Dialogue}

In nearly every First Amendment textbook, the beginning chapters discuss the functions and values of free speech. Chief among those values is the selfgovernment or democratic dialogue function. This function, elaborated in the writings of Alexander Meiklejohn, argues that self-government depends for its survival on a robust democratic dialogue. ${ }^{127}$ Although Meiklejohn advocated an absolute protection of free speech, he limited that protection only to political speech, or speech that was essential for self-government. ${ }^{128}$ Essentially, Meiklejohn saw the First Amendment as existing primarily to serve democratic government, rather than under a marketplace metaphor as striving simply to increase the amount of speech in the system. ${ }^{129}$

\section{8 , at $112-13$}

127. See supra note 61 and accompanying text. For further discussion on Meiklejohn's views, see Steven H. Shiff rin, The First Amendment, Democracy, and Romance 47-56 (1990).

128. For an analysis of Meiklejohn's views, see GARry, The First Amendment, supra note 31, at 77-80; GARRY, AMERICAN VISION, supra note 81, at 74-78.

129. See supra note 61. The First Amendment model of Alexander Meiklejohn views our constitutional system as one of deliberative democracy. It seeks to promote reflective and deliberative debate. This Madisonian model sees the right of free expression as a key part of the system of public deliberation. Consequently, government may impose some controls on the information market that seek to sustain and uplift our system of deliberative democracy. In particular, it may promote political speech at the expense of other forms of speech; and it may discourage some forms of entertainment, if such entertainment comes to crowd out political speech. Obviously, in the Madisonian view, educational and public-affairs programming has a special place. The marketplace view, however, can confuse notions of 
Meiklejohn's primary fear was government tyranny of dissenting political speech, and modern First Amendment doctrines continue to assume that governmental censorship still poses a greater threat to our ability to selfgovern than does "the stupefying effects of ... [a] mass media concerned in the main with neither the true nor the false, but with the unreal [and the] distract[ing]." ${ }^{\text {130 }}$ First Amendment doctrines also seem to presume that our free speech guaranty has the same meaning now as when it was drafted, "even though the evils against which that law was directed do not haunt us as they once did." 131 These doctrines are so much on guard against government censorship that they lose sight of everything else.

Although the media has changed significantly over the past two centuries, constitutional arguments over free speech have changed very little. Free speech advocates tend to look at speech issues in the electronic age in the same way as they examine those issues as they arose during the simplistic print era of the late eighteenth century. Consequently, First Amendment doctrines have failed to confront the realities of the modern media culture and of the role of the individual in that culture. When those doctrines have adjusted to changing technologies, they have tended to adjust to only one-half of the equation, the speech-producing side.

Meiklejohn's theories reflect a fear of the exploitative nature of the electronic mass media: that rather than promoting First Amendment values of collective decision-making, the electronic mass media can corrupt and suffocate them. In our current media culture, those theories seem to have more relevance than does the marketplace model. The democratic dialogue is not being stunted by blockages to speech, but by a flood of distracting speech. The deluge of amusement and entertainment and consumer marketing is crowding out the kind of speech that was far more prominent during the time of Meiklejohn's writing, ${ }^{132}$ and the addictive quality of television viewing steadily intensifies that crowding-out effect. In comparison with advertising and entertainment, political speech continues to lose share in the public communications process; it continues to be underproduced relative to the other kinds of speech. ${ }^{133}$ Hence, within this scenario and within the

\footnotetext{
the individual as consumer with those of the individual as citizen. See supra note 61.

130. Collins \& Skover, supra note 6, at 7, 26.

131. Id. at 25 .

132. See generally Paul Krugman, Turn of the Century, N.Y. Times, June 18, 2000, at D15 (arguing that today's technological advancements are not as important as the ones achieved during the 19th century). 133. Collins \& SKOVER, supra note 6, at 7, 213.
} 
marketplace model, the democratic dialogue function is increasingly threatened. ${ }^{134}$

When Alexander Meiklejohn first articulated his democratic dialogue theory, the danger to free political speech was in governmental restrictions on radical opinion. Congress was targeting the speech and membership of groups such as the Communist Party. ${ }^{135}$ Nonetheless, Meiklejohn's distinction between political and nonpolitical speech remains both relevant and vital; because today, the assault on political speech is coming from the overabundance of nonpolitical speech. Although Meiklejohn once saw absolute First Amendment protection as the only way to guarantee the vitality of political speech, now the only way to achieve such protection may be to confer to individuals a private right to censor out distracting, nonpolitical speech.

In addition to filtering out unwanted information, a private right to censor may actually serve to open up channels of political speech. If people have greater power to control the amount and kind of speech to which they are subjected, there may be fewer calls for government censorship. ${ }^{136}$ A private right to censor may also lessen the chilling effect that unwanted or offensive speech has on political speech. For instance, if parents do not have to worry about their children watching "The Howard Stern Show," perhaps they will subscribe to cable and have a chance to watch CNN, The History Channel, MSNBC, or Fox News. If parents do not have to constantly monitor their children's use of the Internet, perhaps they will allow them to explore that vast

134. "Discourse is dying in America, yet everywhere free speech thrives." Id. at xix. On average, Americans spend a greater percentage of their spare time (on average, 50.5 hours per week) watching television than engaging in almost all other activities taken together. Id. at 5. Young people consume over 100 commercials daily. $I d$.

135. See, e.g., Am. Communications Ass'n v. Douds, 339 U.S. 382 (1950).

136. This view was expressed by Rep. Thomas Bliley (R-Va.) during a 1988 congressional debate on the issue:

There is no completely effective way to prevent children from being exposed to 'indecent' or 'obscene' dial-a-porn so long as it is lawfully and commercially marketed.” 134 CONG. REC. H1693 (daily ed. Apr. 19, 1988) (statement of Rep. Bliley). Bliley went on to note: "[D]ial-a-porn is presently in the home whether the homeowner wants it or not. Today one cannot have telephone service in the privacy of one's family environment without being required to have dial-a-porn with it. Families with children must give up telephone service to be left alone from exposure of their children to this intruder."

Id. at H1694. Also, in Pacifica, the lack of user control over content was used to justify FCC regulation. FCC v. Pacifica Found., 438 U.S. 726, 748-50 (1978) (justifying FCC regulation because user control over context was limited). "A medium that offers individual users the ability to exercise greater control over the content that they (and their children) receive might reduce the legislative zeal for content regulation." Berman \& Weitzner, supra note 21, at 1632. 
store of information more freely. Thus, by giving people the ability to control unwanted speech, a private right to censor may open up opportunities for serious speech. ${ }^{137}$

Alexander Meiklejohn recognized that in a democratic society with a robust media, the roles of consumer and citizen could easily become blurred or even subsumed. ${ }^{138}$ A media culture can actually undermine a democratic culture, if the speech of that media culture centers on amusement and consumption and tends to crowd out political or public interest speech. For if the First Amendment means anything, it is that speech is not a consumer commodity, like blue jeans.

\section{F. The Erosion of Community Standards}

The First Amendment does not protect obscenity; and in Roth v. United States, ${ }^{139}$ the Court held that one test of obscene speech was whether it violated community standards of decency. With the Internet, however, the integrity of community standards is being eroded. Communities now transcend geographic boundaries. ${ }^{140}$ On the Internet, people across the world can exchange obscene speech. If another person unsuspectingly taps into this exchange, is the community standard to be determined by the locale in which the person lives, or is it to be determined by the virtual community which generated the speech? ${ }^{141}$ This issue has become a much-debated one among First Amendment scholars. ${ }^{142}$ Whatever its resolution, one conclusion is

137.

In order for interactive media to ... win strong First Amendment protections from regulation like those accorded to print, . . . there must be sufficient user control to enable users to choose what information they want to receive, and what they want to keep out, thus eliminating the rationale for government to step in and protect various parts of society with intrusive content regulations.

Berman \& Weitzner, supra note 21, at 1621.

138. It is questionable as to how valuable or informed the decisions of viewers and listeners are, since they pay nothing for the broadcasting product; because of the role of advertisers in determining content, what is being provided in the communications market is not necessarily the same as what viewers would like to see.

139. Roth v. United States, 354 U.S. 476 (1957).

140. In 1999, the Internet was believed to connect more than 159 countries and over 109 million users. SCHACHTER, supra note 4, at 16. An estimated five million e-mail messages were sent around the world each minute. $I d$. at 6 . By 2000 , the number of worldwide users was estimated at 332 million; and Internet traffic is estimated to double every 100 days. $I d$.

141. See Sable Communications, Inc. v. FCC, 492 U.S. 115, 124 (1989) (describing defendant's argument that it should not be compelled to tailor its dial-a-porn messages to the standard of the least tolerant community).

142. When obscene content is disseminated over the Internet, the question is what is the relevant 
certain: the old notion of community standards as a protection against obscenity is being weakened. In a virtual world, people cannot depend on the sensibilities of their neighborhoods, towns and cities to shield out obscenity. Therefore, they will need some stronger weapon that they can use on their own.

\section{G. Empowerment of the Child Protection Interest}

In almost every case involving indecent speech, the courts address the most obvious purpose of any attempted restrictions on such speech: that of the protection of children. The courts have gone to great lengths to craft out special constitutional protections for children. ${ }^{143}$ However, this concern with shielding minors from indecent speech ${ }^{144}$ erodes when it comes in conflict with the speech rights of adults and the interests of the marketplace model. Few measures shielding minors from indecent speech are upheld if they have any restraining effect on the ability of adults to access such speech. ${ }^{145}$ Consequently, the child protection interest frequently loses out to the abundance goal, to the idea that any burden on speech is the equivalent of an unconstitutional infringement.

A private right to censor, however, might change this lopsided comparison. It might finally give some real constitutional weight to society's interest in protecting children from indecent speech, and it might create more of a balance between a parent's right to exclude offensive speech and an adult's right to receive it. ${ }^{146}$

community. The virtuality of cyberspace arguably "erodes the rationale for applying local community standards as the definitive touchstone for whether the materials are, in fact, obscene." See, e.g., William S. Byassee, Jurisdiction of Cyberspace: Applying Real World Precedent to the Virtual Community, 30 WAKE FoREST L. REV. 197, 204 (1995) (arguing the virtuality of cyberspace "erodes the rationale for applying local community standards as the definitive touchstone for whether the materials are, in fact, obscene"); see also Goldstein, supra note 6, at 155 (arguing that "the Internet ha[s] made the problem [of community standards] even more complicated").

143. See New York v. Ferber, 458 U.S. 747, 757 (1982); Ginsberg v. New York, 390 U.S. 629, 631-33 (1968) (upholding requirements that restricted the distribution even of printed matter to children).

144. See Steven Shiffrin, Government Speech, 27 UCLA L. REV. 565, 647 (1980) ("children are the Achilles heel of liberal ideology").

145. See, e.g., Butler v. Michigan, 352 U.S. 380, 383-84 (1957) (holding that legislation cannot be so restricted that it "is to reduce the adult population of Michigan to reading only what is fit for children").

146. And with some types of user controls that would enable people to limit access to certain kinds of material on their TVs or PCs, the goal of indecency regulations - the protection of children - could be achieved without intrusive government regulations. See Nachbar, supra note 1, at 309-10 (arguing for the constitutionality of a content-neutral regulatory scheme aimed at "empowering" (emphasis added) parents to filter the content coming into their home); see also Wagner, supra note 42, at 788 (discussing the 


\section{A Private Right to Censor Outside the Home}

\section{A. The Extension of the Captive Audience Rule}

The captive audience doctrine has been used to give people a right to be free of unwanted speech in certain kinds of places and under certain conditions. ${ }^{147}$ When employing this doctrine, courts elevate the desires of the audience to exclude speech over that of the speaker to convey it. Aside from the few cases in which it has been applied, the captive audience doctrine has not exerted a prevalent influence in First Amendment jurisprudence. Courts have rarely employed the doctrine to justify speech restrictions. Instead, as the Court ruled in Playboy Entertainment, audiences are generally expected to assume the burden of averting their eyes whenever they are confronted with unwanted or offensive speech. ${ }^{148}$ Striking down a law which in effect required cable operators offering sexually oriented programming to confine their programs to the hours between 10 p.m. and 6 a.m., the Court recognized the strong state interest in shielding young viewers from such programming, but nonetheless held that the law constituted too great a burden on adult viewers. In reaching its decision, the Court found that a less restrictive alternative was available to parents who wished to keep their children from watching indecent programming. ${ }^{149}$ This alternative required the cable operator, ““[u]pon request by a cable service subscriber ... [t] fully scramble or otherwise fully block'

government interest in supporting parents "in controlling the sexual and violent content of the material their children are exposed to on the Internet"). Wagner characterizes this as "an enabling interest rather than a content-based interest," and that as such it should be measured by a lower level of constitutional scrutiny. Id. at 788-89.

147. See Lehman v. City of Shaker Heights, 418 U.S. 298 (1974) (upholding a ban on political advertisements in public transit vehicles, on the grounds that commuters are a captive audience). But Professor Balkin argues that "in most cases the protection of children and parental control over children are much better justifications for regulation of content than captive audience doctrine." Balkin, supra note 54, at 2312 .

148. United States v. Playboy Entm't Group, Inc., 529 U.S. 803, 813 (2000) (citing Cohen v. California, 403 U.S. 15, 21 (1971)). Playboy involved a challenge to a provision of the Telecommunications Act of 1996 which "require[d] cable television operators who provide channels 'primarily dedicated to sexually-oriented programming' either to 'fully scramble or otherwise fully block' those channels or to limit their transmission to hours when children are unlikely to be viewing, set by administrative regulation as between 10 p.m. and 6 a.m." Id. at 806 . Even before the enactment of this provision, cable operators used signal scrambling to limit access to certain programs to paying customers. But this scrambling was imprecise and often led to "signal bleed." The purpose of this provision was "to shield children from hearing or seeing images resulting from such signal bleed." Id.

149. Id. at 816 . 
any channel the subscriber does not wish to receive." ${ }^{50}$ For this alternative to work, the cable operator would have to provide "adequate notice" to their subscribers that certain channels would broadcast sexually-oriented programming, that signal bleed may occur, that children might then see portions of the programming, and that parents could contact the cable operator to request a channel blocking device. ${ }^{151}$ The original notice, apparently, would be provided as an insert in the monthly cable bills.

Obviously, if the justices in the majority saw this alternative as reasonable, they have never tried to contact their cable operator. This was the point made in Justice Breyer's dissent, which focused particularly on the issue of relative burdens. First, Justice Breyer noted that the law in question placed a burden on adult programmers, not a ban. ${ }^{152}$ Second, he observed that the law applies only to channels that "broadcast virtually $100 \%$ sexually explicit material." 153 And third, he recognized that, because of signal bleed, approximately twenty-nine million children were potentially exposed each year to sexually explicit programming. ${ }^{154}$ Given the compelling interests of child protection at issue, Justice Breyer concluded that the majority's proposed alternative was not at all an effective alternative. ${ }^{155} \mathrm{He}$ cited evidence in the record of all the problems people had experienced in trying to get their cable operator to block certain channels, problems that come as no surprise to anyone who has ever tried to get their cable company to fix something. ${ }^{156}$

Not only did Justice Breyer find fault with the proposed alternative, but he argued that the original law was not constitutionally defective. It served, he argued, "the same interests as the laws that deny children access to adult cabarets or X-rated movies," ${ }^{157}$ and its objective was perfectly legitimate. Where over twenty-eight million children have no parents at home after school, and where children may spend afternoons and evenings watching television outside of the home with friends, the time-channeling law offered

150. Id. at 809-10.

151. Id. at 810 .

152. See id. at 845 (Breyer, J., dissenting) ("Adults may continue to watch adult channels, though less conveniently, by watching at night, recording programs with a VCR, or by subscribing to digital cable with better blocking systems.").

153. Id. at 839 (Breyer, J., dissenting).

154. Id. at 839 .

155. Id. at 841 .

156. Id. at $843-44$.

157. Id. at 842 . 
"independent protection for a large number of families."158 Thus, finding that the law served a compelling interest, that it did not constitute a ban on speech, and that there were no less restrictive alternatives, Justice Breyer argued that the law should have been upheld.

Reflecting the arguments in favor of a private right to censor, Justice Breyer argued that the First Amendment was not intended to leave millions of parents helpless in the face of media technologies that bring unwanted speech into their children's lives. ${ }^{159}$ Under Justice Breyer's logic, and contrary to existing First Amendment doctrine, an opt-in law may be just as valid as an opt-out law. This means that a law requiring a person desiring adult programming to affirmatively direct that it be offered her would be judged on the same level as a law requiring someone not wanting adult programming having to direct that such programming be blocked.

A Ninth Circuit decision in Bland v. Fessler followed the parameters of a private right to censor when it applied the captive audience doctrine to new technologies. ${ }^{160}$ In upholding a restriction on telemarketers' use of automatic dialing and announcing devices ("ADADs"), the court first ruled that ADADs were much more disruptive than door-to-door solicitors, and "more of a nuisance and a greater invasion of privacy' than telemarketing with live operators." ${ }^{161}$ The court then held that the regulation at issue did not amount to an absolute ban on speech, since the use of ADADs were permitted so long as the called party consented to the message, although it is difficult to imagine that many people would ever so consent. ${ }^{162}$ The court also found that a do-not call list was not a less restrictive means of accomplishing the government's objective, since a do-not call list would place the burden on the public to stop disruptive ADAD calls from arriving at their homes. Nor did the court accept the argument that people should be left to themselves to combat ADADs by turning off their ringers or screening their calls or simply hanging up on the prerecorded calls. ${ }^{163}$ In other words, the court did not impose an "averting one's eye's" burden on the recipients of the calls; it did not place all the burden on the recipient to opt-out. As does a private right to censor, the Bland

158. Id.

159. Id. at 846 .

160. Bland v. Fessler, 88 F.3d 729 (9th Cir. 1996). The case involved a challenge to a California law regulating automatic dialing and announcing devices. The law prohibited the use of the devices unless a live operator first identified the calling party and obtained the called party's consent to listen to the prerecorded message. $I d$. at 731 .

161. Id. at 733 .

162. $I d$.

163. Id. at 736 . 
decision recognizes that in a world pervaded by media technologies, the captive audience doctrine can have a wider application in First Amendment jurisprudence.

It seems to be widely assumed that technology gives people greater power to avoid unwanted speech; in truth, the opposite appears to be the case. Sitting in the computer section of the library, a person can glance around and see everyone else's screens. Television programs prohibited by parents are graphically advertised during other programs. Pressing the "seek" button on a radio produces whatever station has a clear signal. Huge television screens run day and night in public places. Internet terminals are available in coffee houses and even fast-food restaurants. The captive audience doctrine is based on the belief that people should have some privacy, in certain circumstances, from always being exposed to unwanted speech. ${ }^{164}$ If privacy is a constitutional right, why should it be completely subservient to the rights of speakers? If people have a privacy right to go to a store and buy contraceptives, should they not have a privacy right to exclude unwanted media sources from influencing their children's sexual development?

\section{B. Locales in Which the Private Right to Censor Might Be Used}

Even outside the home, there are venues in which people should have a right to be free of unwanted media speech. ${ }^{165}$ In general, such venues would be places where children are essentially captive audiences, places where children are intended to be, and where parents should not expect offensive speech to intrude. Schools, libraries, and parks, at least regarding electronic media, would be examples of such places. Just as individuals generally carry

164. This argument was made by Justice Douglas in his dissent in Public Utilities Commission v. Pollack, 343 U.S. 451, 468 (1952) (Douglas, J., dissenting). There, he argued that people should have a right to be let alone from unwanted messages while riding a street car, because most of them probably had no choice but to use public transportation. This same argument applies today, in that many people have no real choice in their use of the Internet or cable television. $C f$. Lehman v. City of Shaler Heights, 418 U.S. 298, 306-07 (1974) (Douglas, J., concurring) ("if we turn a bus into a newspaper, we take great liberties with people who because of necessity become riders and at the same time captive listeners").

165. The courts have already upheld restrictions that apply across-the-board and outside the home, and not just individually on a home-by-home basis. See Dial Info. Servs. Corp. v. Thornburgh, 938 F.2d 1535 (2d Cir. 1991); Info. Providers' Coalition v. FCC, 928 F.2d 866 (9th Cir. 1991) (regulating everyone's access to dial-a-porn so as to protect the children of parents who did not wish them to hear this particular kind of speech). See also Balkin, supra note 54, at 2312 (arguing that captive audience doctrine "should not focus on particular spaces like the home. [I]t should regulate particular situations where people are particularly subject to [unwanted speech]."). 
with them the right of sexual privacy wherever they go, so too should children carry with them the right to be free of intruding and offensive media speech.

A six-part test determines whether a private right to censor can exist in a venue outside the home: there must be a captive audience; that audience must be children; there must be a reasonable chance that the children will be exposed to the unwanted speech; the unwanted speech must be of a type that parents have a legitimate interest in avoiding (such types, as established through previous case law, include sexually explicit speech and graphic violence); the unwanted speech cannot constitute political speech in the Meiklejohn scheme; and the exercise of the private right to censor cannot effectuate a total ban on the unwanted speech. The private right to censor can shift the burdens relating to accessing the speech, making the listener opt-in rather than forcing the excluder to opt-out, but it cannot rise to the level of a complete ban or prior restraint on that speech. ${ }^{166}$

The intermingling of the private right to censor with Alexander Meiklejohn's theory of free speech attempts to incorporate what the courts have long recognized: that not all speech is of equal importance or priority under the First Amendment. Unlike Meiklejohn's theory, the private right to censor does not deny First Amendment protection to nonpolitical speech; it just holds that for some nonpolitical speech the right to censor may be stronger than the right to access without burden. Put another way, different kinds of speech may have different censorship quotients, and a higher censorship quotient may justify greater burdens of access. Therefore, the test for a private right to censor may very well turn out differently for different kinds of speech. In an age of speech abundance, the First Amendment should not view speech/censorship issues simply as an on-off valve, but as a faucet with varying degrees of "on."

166. Under a private right to censor, the time-channeling and segregate-and-block restrictions challenged in the Playboy Entertainment and Denver Area cases would probably have been upheld. See generally Denver Area Educ. Telecomm. Consortium, Inc. v. FCC, 518 U.S. 727 (1996); United States v. Playboy Entm't Group, Inc., 529 U.S. 803 (2000). And if the state may pass a law that prohibits corporations from contributing to candidates for state offices-a law which obviously burdens the First Amendment rights of those corporations, yet is supported by the compelling state interest in preventing corruption or the appearance of corruption in state elections - then it should be able to enact measures which empower an individual's right to censor. See Austin v. Mich. Chamber of Commerce, 494 U.S. 652 (1990). If the government has a compelling interest in toning back the voices of corporations, finding them to be disproportionate to the public support for the view conveyed, then the government should have an interest in letting individuals tone back the media voices that constantly intrude into their lives. 


\section{ViII. An Affirmative Right to Censor: the State Action Argument}

Even if Congress does not enact legislation granting a private right to censor (or basing certain speech restrictions on a private right to censor), there might still exist an implied, affirmative constitutional right of private censorship that the courts must recognize. Such an affirmative right would arise out of a variation of the state action argument.

As it now stands, cable television places many obstacles in the path of a person's ability to privately censor. Channels are not segregated by content, thus preventing an unsuspecting viewer from avoiding unwanted speech as he or she surfs through the channels. Nor is content blocked into various time slots, depending on the sexual explicitness or graphic violence of the content. Viewers are completely at the mercy of the cable provider as they scroll through the programming. The only real, easily implemented choice a viewer has is to add more premium channels. There is virtually no effective way to censor unwanted speech, other than to opt-out of the system altogether.

If cable providers were entirely private actors, there would be no First Amendment issue with their mere failure to provide an effective right of private censorship. However, there is a strong argument that the cable industry is not just another private enterprise. It is governed by pervasive federal regulations. ${ }^{167}$ The government has, from the start, shaped the development of cable television. The monopoly status that cable enjoys is the result of government granted franchises. Consequently, it can be argued that, in the context of a private right to censor, this historic and pervasive government involvement with cable confers upon it a state action component. ${ }^{168}$

167. Beginning in the early 1960 s, the FCC proceeded to construct one of the most elaborate schemes of regulation. See Robinson, supra note 43, at 932. See also Cass R. Sunstein, Free Speech Now, 59 U. CHI. L. Rev. 255, 272 (1992) (arguing on behalf of finding state action). Professor Sunstein argues that "[g]overnment gives broadcasters property rights in their licenses, and their exercise of those rights is a function of law in no subtle sense." Id. Sunstein further argues that "a right of exclusive ownership in a television network is government conferred." Id.

168. See Fiss, supra note 3, at 257. "Every media organization received significant benefits from the state." Id. at 266.

In addition, the government has played a leading role in the development of television technology, and it continues to provide distinct benefits and privileges to the various entities within the television industry. Each over-the-air broadcaster receives a license from the federal government that gives it exclusive permission to use a portion of the electromagnetic spectrum; cable operators receive easements from local governments that permit them to run their wire cable through town streets; and public television stations receive direct subsidies from all levels of government. 
By restricting the ability to censor unwanted speech, cable providers infringe on their audience's freedom of expressive association. ${ }^{169}$ For without an effective ability to block unwanted speech, the audience is hindered in its capacity to associate, in a speech context, according to certain beliefs or ideologies. ${ }^{170}$ These associations are constantly susceptible to the intrusion of unwanted, objectionable speech and images. ${ }^{171}$

Under the doctrine of unconstitutional conditions, it can be argued that the power of the television media has eroded the individual's freedom of expressive association. ${ }^{172}$ Thus, even though a person has no right to receive cable television, the government may not provide that benefit through the grant of a monopoly franchise to the cable operator, and then violate the person's speech rights by not providing a means to censor out what the individual does not want. Furthermore, as the power of the government supported cable franchise increases, constitutional doctrines must be adapted so as to correspondingly increase the individual's power to exercise his or her freedom of expressive association. ${ }^{173}$ One adaptation, of course, would be a private right to censor.

\section{CONCLusion}

There has always been a strong absolutist voice within First Amendment scholarship - a scholarship committed to the abundance goal of the marketplace model. As Justice Black did, this scholarship cites the absolutist

Id.

169. See generally Boy Scouts of Am. v. Dale, 530 U.S. 640 (2000); Roberts v. United States Jaycees, 468 U.S. 609 (1984) (discussing concept of freedom of expression).

170. As one First Amendment scholar has written, "if the development of filtering systems enables individuals to form and move among a set of diverse normative communities, then banning filters ... interferes with rather than promotes normative pluralism. On this view, a private choice of what speech to discriminate against is itself an expressive act . . ." Kathleen M. Sullivan, First Amendment Intermediaries in the Age of Cyberspace, 45 UCLA L. REV. 1653, 1681 (1998).

171. See generally INGRAM, supra note 28, at 106 (discussing the concept of government intervention to pressure the state and the political and social expressions of its citizens).

172. One of the most succinct statements of the doctrine of unconstitutional conditions is from the Supreme Court's decision in Perry v. Sindermann: “[E]ven though a person has no right to a valuable governmental benefit ... ., the government ... may not deny a benefit to a person on a basis that infringes his constitutionally protected interests—especially, his interest in freedom of speech.” 408 U.S. 593, 597 (1972).

173. Rodney Smolla, The First Amendment: Freedom of Expression, Regulation of Mass Media, Freedom of Religion 156 (1999). For instance, the Fourth Amendment's guarantee against unreasonable searches was extended by the Supreme Court to cover electronic eavesdropping, even though the framers of the Constitution could not have contemplated such a "search." Id. 
language of the First Amendment. But this historical stance differs sharply from the environmental stance that is so often taken on the Second Amendment. For the latter, scholars argue that social and political realities have changed so much since the late eighteenth century that the Second Amendment should be interpreted accordingly. They argue that the Framers would never have envisioned urban gangs toting automatic weapons on their way to a drug deal. But if the Second Amendment is to be interpreted in such an environmental manner, should not the First Amendment also be? Indeed, the Framers never would have envisioned the kind of speech now so prevalent on television. They never would have envisioned that media speech would amount to such a flood over society, and that electronic images would be as pervasive, or even more so, than a breath of clean air. ${ }^{174}$

174. See United States v. Playboy Entm't Group, Inc., 529 U.S. 803, 831 (2000) (Scalia, J., dissenting) (quoting Ginzberg v. United States, 383 U.S. 463, 467, 472 (1966)) ("We have recognized that commercial entities which engaged in 'the sordid business of pondering by deliberating emphasiz[ing] the sexually provocative aspects of [their nonobscene products], in order to catch the salaciously disposed; engaged in constitutionally unprotected behavior."'). 